\title{
An integrated approach to delimiting species borders in the genus Chrysotoxum Meigen, 1803 (Diptera: Syrphidae), with description of two new species
}

\author{
Zorica Nedeljković ${ }^{1,4}$, Jelena Ačanski ${ }^{1}$, Mihajla Đan², Dragana Obreht-Vidaković ${ }^{2}$, Antonio Ricarte ${ }^{1,3}$, Ante Vujić \\ ${ }^{1}$ University of Novi Sad, BioSense Institute - Research Institute for Information Technologies in Biosystems, Trg \\ Dr Zorana Đinđića 1, 21000 Novi Sad, Serbia \\ ${ }^{2}$ University of Novi Sad, Department of Biology and Ecology, Trg Dositeja Obradovića 2, 21000 Novi Sad, Serbia \\ ${ }^{3}$ Present address: University of Alicante, Centro Iberoamericano de la Biodoversidad (CIBIO), 03690 San Vicente \\ del Raspeig, Alicante, Spain \\ ${ }^{4}$ Email: zoricaned14@gmail.com
}

Key words: Balkan Peninsula, C. montanum sp. nov., C. orthostylum sp. nov., ecological niche, geometric morphometry, lectotype, mtDNA COI sequences, Syrphinae

\begin{abstract}
Integrative taxonomy tests the validity of taxa using methods additional to traditional morphology. The existence of two different morphotypes in specimens identified as Chrysotoxum vernale Loew (Diptera: Syrphidae) prompted their taxonomic study using an integrative approach that included morphology, wing and male-surstylus geometric morphometrics, genetic and ecological analyses. As a result, a new species is recognised, Chrysotoxum montanum Nedeljković \& Vujić sp. nov., and $C$. vernale is re-defined. A lectotype and paralectotypes are designated for $C$. vernale to stabilize this concept. An additional species, Chrysotoxum orthostylum Vujić sp. nov., with distinctive male genitalia is also described. The three species share an antenna with the basoflagellomere shorter than the scape plus pedicel and terga with yellow fasciae not reaching the lateral margins. This study confirms the value of integrative approach for resolving species boundaries.
\end{abstract}

\section{Contents}

\begin{tabular}{|c|c|}
\hline Introduction & 285 \\
\hline 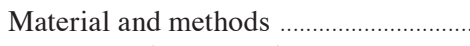 & 286 \\
\hline 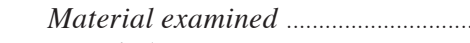 & 286 \\
\hline Morphology ................... & 286 \\
\hline 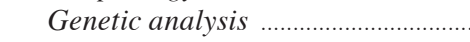 & 86 \\
\hline Geometric morphometry ............ & 87 \\
\hline 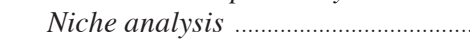 & 288 \\
\hline 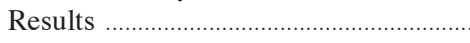 & 288 \\
\hline 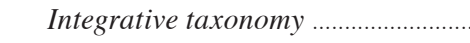 & 88 \\
\hline 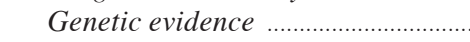 & 285 \\
\hline Geometric morphometric evidence & 290 \\
\hline 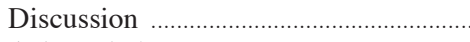 & 291 \\
\hline Acknowledgements & \\
\hline References .................. & \\
\hline Appendix .................... & \\
\hline
\end{tabular}

\section{Introduction}

Worldwide, syrphids (Diptera: Syrphidae) play important ecological roles in nature. Adults are usually conspicuous flies that feed on pollen and nectar from a wide range of plants in numerous habitats (Rotheray and Gilbert, 2011). In Europe, syrphids are one of the better studied Diptera families. However, the taxonomy of certain groups is still provisional and uncertain, such as the genus Chrysotoxum Meigen, 1803 (Speight, 2013).

Chrysotoxum species are present in all bio-geographic regions except for Australasia. In the Palaearctic region 71 species are recorded, 24 of which are present in Europe (Vockeroth, 1969; Violovitsh, 1974; Peck, 1988; Nedeljković et al., 2013). These waspmimics can be separated from other syrphid genera by the yellow and black body colouration (yellow maculae in thoracic pleura and yellow fasciae in abdominal terga), the very long antenna and the convex, margined abdomen (Thompson and Rotheray, 1998). Chrysotoxum adults are found in many habitat types (Speight, 2013) and their poorly known larvae are associated with ants and/or root aphids (Rotheray, 1994).

The taxonomy of certain Chrysotoxum species has proven difficult due to subtle morphological differences (Nedeljković et al., 2013) and high levels of intra-specific variability (Sang-Wook and Ho-Yeon, 2013). In these circumstances, integrative taxonomy is useful for testing species concepts. Integrative taxonomy is a multidisciplinary approach to taxonomy that aims to delimit the units of life's diversity from different and complementary perspectives (e.g. comparative 
morphology, population genetics, ecology, behaviour) (Dayrat, 2005). Many species have been described among syrphids using an integrated approach (e.g. Marcos-García et al., 2011; Radenković et al., 2011; Skevington and Thompson, 2012; Locke and Skevington, 2013; Vujić et al., 2013; Haarto and Ståhls, 2014). To find genetic differences between similar species, analyses of both mitochondrial (e.g. COI) and nuclear (e.g. ITS2) genes have been used (e.g. Masetti et al., 2006; Vujić et al., 2012, 2013). In other Diptera families such as Drosophilidae wing shape is highly dependent on genetic inheritance and therefore minimally affected by temperature (Birdsall et al., 2000), altitude, and season (Bitner-Mathé and Klaczko, 1999). Wing morphometry has been used in integrative taxonomic studies of syrphids (e.g. Ludoški et al., 2008; Francuski et al., 2009, 2011; Vujić et al., 2013; Nedeljković et al., 2013). Male-genitalia morphometry has also been used (Nedeljković et al., 2013). Ecology plays an important role in diversification processes and ecological analyses have proven useful in supporting species concepts (Bond and Stockman, 2008; Nosil, Harmon and Seehausen, 2009; Wooten and Gibbs, 2012; Zhu et al., 2013). Funk et al. (2006) reported a highly significant positive association between ecological divergence and reproductive isolation across taxa. Although ecological analyses have not been used in integrative taxonomy of Syrphidae, unpublished data suggest they could be important (Ačanski J, Miličić M, Likov L, Radenković S, Vujić A, unpubl. data).

A preliminary examination of named specimens of Chrysotoxum vernale Loew, 1841 resulted in the identification of two different morphotypes according to the colour of long pile on thoracic scutum of males: yellow (morphotype A) and black (morphotype B) (Nedeljković, 2011). In addition, a new Chrysotoxum taxon sharing with morphotypes $\mathrm{A}$ and $\mathrm{B}$ an antenna with basoflagellomere shorter than scape and pedicel together and abdominal terga with yellow fasciae not reaching the lateral margins was recognized. The main objective of the present study is to test using an integrated approach, whether these morphotypes correspond to different species.

\section{Material and methods}

\section{Material examined}

A total of 400 Chrysotoxum specimens were examined. They were collected in Austria, Bosnia \& Herze- govina, Croatia, Finland, FYR Macedonia, Germany, Greece, Italy, Kyrgyzstan, Montenegro, Poland, Serbia and Turkey, by various collectors, from 1860 to 2013 . The following abbreviations are used for where specimens are deposited: FSUNS, Department of Biology and Ecology, Faculty of Sciences, University of Novi Sad, Serbia; MZH, Zoological Museum, Finnish Museum of Natural History, Helsinki, Finland; NHMW, Naturhistorisches Museum, Wien, Austria; ZMHB, Zoologishes Museum of the Humbolt University, Berlin, Germany; RMNH, Naturalis Biodiversity Center, Leiden, The Netherlands; DD, Dieter Doczkal's and AS, Axel Ssymank's private collection, Germany. In addition, type material was also examined in the collection at Zoologishes Museum of the Humbolt University, Berlin (ZMHB) and Museo Zoologico La Specola, Firenze, Italy (LSF). Material examined is detailed in Table S1 (Supplementary information). Only type material is detailed in the text.

\section{Morphology}

To describe and diagnose species, characters were studied using a Ceti® binocular microscope. Colour characters always refer to dry specimens. Body size was measured as the length ('L') from the tip of the frontal prominence (excluding antenna) to the tip of the abdomen. Proportional length of the antennal segments is given as a ratio ('r') of $x$ : $y: z$ (' $x$ ', scape; ' $y$ ', pedicel; ' $z$ ', basoflagellomere). Measurements were made using an eye-piece micrometer. Morphological terms follow Thompson (1999).

\section{Genetic analysis}

Two or three legs of each specimen were used for total genomic DNA extraction from 25 Chrysotoxum dry specimens (Table S2), following Chen et al. (2010). Material analysed included 22 specimens of the $C$. vernale $\mathrm{A}$, two specimens of the $C$. vernale $\mathrm{B}$ and one of third Chrysotoxum species. DNA voucher specimens are deposited in FSUNS.

The 5' region of cytochrome c oxidase I gene (COI) was amplified using forward primer LCO (5'-GCTCAACAAATCATAAAGATATTGG-3') and reverse primer HCO (5'-TAAACTTCAGGGTGACCAAAA AATCA-3') (Folmer et al., 1994). The universally conserved primers were used for amplifying and sequencing the 3' region of COI: forward primer C1-J-2183 (5'-CAACATTTATTTTGATTTTTTGG-3') (alias JERRY) and reverse primer TL2-N-3014 (5'-TC- 
CAATGCACTAATCTGCCATATTA-3') (alias PAT) (Simon et al., 1994).

PCR reactions were carried out in $25 \mu 1$ reactions containing: approx. $50 \mathrm{ng}$ of DNA, 2 pmoles of each primer, $0.2 \mu \mathrm{l}$ of DNA polymerase $(5 \mathrm{U} / \mu \mathrm{l}), 2.5 \mathrm{mM}$ $\mathrm{MgCl}_{2}, 2.5 \mu \mathrm{l} 10 \times$ Taq Buffer, $0.1 \mathrm{mM}$ of each nucleotide and ultra-pure water. Thermocycler conditions were initial denaturing at $95^{\circ} \mathrm{C}$ for $2 \mathrm{~min}, 29$ cycles of $30 \mathrm{~s}$ denaturing at $94^{\circ} \mathrm{C}, 30 \mathrm{~s}$ annealing at $49^{\circ} \mathrm{C}, 2 \mathrm{~min}$ extension at $72^{\circ} \mathrm{C}$, followed by a final extension of 8 $\min$ at $72^{\circ} \mathrm{C}$.

Expected size of amplification products was confirmed with a standard 1.5\% agarose gel electrophoresis. The remaining product was purified using Exonuclease I and Shrimp Alkaline Phosphatase enzymes following the manufacturer's instructions (Thermo Scientific, USA). All sequencing reactions were performed using the Big Dye Terminator Kit v3.1. (Applied Biosystems, USA) following the manufacturer's protocol; sequences were generated on ABI 3730xl DNA Analyzer and deposited in GenBank (accession numbers: KR019039- KR019063).

Sequences were aligned using the ClustalW algorithm (Thompson et al., 1994) as implemented in BioEdit 7.0.9.0 (Hall, 1999), with final adjustments performed manually. The data set containing 5 ' region COI sequences had final length $542 \mathrm{bp}$, and the final length of dataset containing 3' region COI sequences was 625bp. The final dataset with $25 \mathrm{mtDNA}$ COI sequences was created by merging sequence information of 3' and 5' COI regions. Phylogenetic analysis for all species was performed using Maximum Likelihood (ML) method, and a tree was created in MEGA 6.0 (Tamura et al., 2013). The Maximum Likelihood method applied is based on the Tamura-3 parameter model (T92+ $\gamma$; $\gamma=0.05)$ of nucleotide substitution as defined in MEGA 6.0 (Tamura et al., 2013). Statistical support of internal nodes was calculated with 1000 bootstrap repetitions. Eumerus flavitarsis Zetterstedt, 1843 (AY212782) was used as an outgroup taxon. Median-joining (MJ) network (Bandelt et al., 1999) was constructed using the software Network 4.6.1.1 (available at http://www.fluxusengineering.com/sharenet.htm). The network was constructed using equal weights for all the mutations and setting parameter $\varepsilon$ to zero in order to restrict the choice of feasible links in final network.

\section{Geometric morphometry}

Morphometric analyses were used to characterise all taxa. High-resolution pictures of wings and surstyli were made using a Leica DFC320 video camera attached to a Leica MZ16 stereomicroscope. A video camera was connected to a PC computer in which the software to make pictures was installed. Landmarks (wings) and semi-landmarks (surstyli) were drawn on every picture using TpsDig 2.05 software (Rohlf, 2006). One-way analysis of variance (ANOVA) and Tukey's post hoc test were used to test differences in wing centroid size between sexes and taxa. Wing centroid size is the square root of the sum of the squared distances between the centre of the wing and each landmark (Zelditch et al., 2004). Multivariate analysis of variance (MANOVA), canonical variate analysis (CVA) and discriminant function analysis (DA) were used to test differences in wing and surstylus shape between sexes and taxa. Statistical analyses were made using Statistica ${ }^{\circledR}$ for Windows (StatSoft, 2012). For males and females of morphotypes A and B analyses were carried out separately.

Variation of wing size and shape was studied in 249 specimens of all three taxa following Bookstein (1991). The right wing of each specimen was taken off by means of micro-scissors and then mounted in Hoyer's medium (Anderson, 1954) on a microscopic slide. Wings are archived and labelled using unique codes shown in Table S1 (Supplementary information). Sixteen homologous landmarks were chosen at vein intersections and terminations throughout the wing; landmarks were selected in positions of the wing that could be easily recognisable at any time (Fig. 1). To reduce the statistical errors due to the low number of specimens (Arnqvist and Mårtensson, 1998) wings of Chrysotoxum orthostylum Vujić sp. nov., were digitized 10 times. Generalised least squares Procrustes superimposition (GLS) was used to minimise non-shape variations in location, scale and orientation of wings, and also to superimpose the wings in a common coordinate system (Rohlf and Slice, 1990; Zelditch et al., 2004). GLS, wing centroid size and partial-warp scores were computed using CoordGen7.14 and CVAgen7.14a, which are part of IMP package (Sheets, 2012). MorphoJ v2.0 was used to visualize the thin-plate spline deformation (Klingenberg, 2011).

For surstyli, outline shape was studied. Surstyli of 51 Chrysotoxum males were analyzed: 21 of morphotype $\mathrm{A}$ and 30 of morphotype $\mathrm{B}$. The right surstylus was taken off using pins. Surstyli were mounted in Hoyer's medium on a microscopic slide and immobilized with a cover slip. In the absence of clearly-identifiable, homologous, anatomical loci, 30 semi-landmarks were generated (Fig. 2). For each specimen 

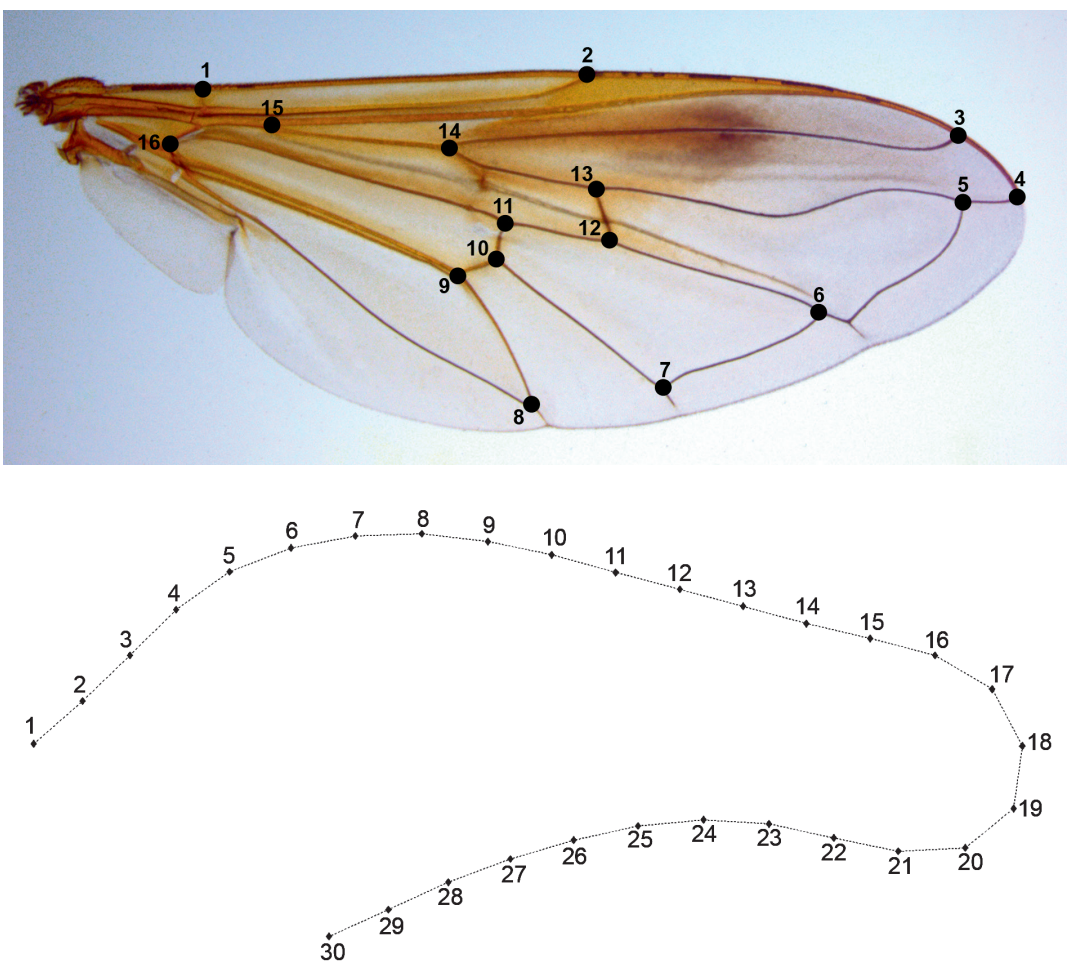

Fig. 1. Location of the 16 analysed landmarks on the right wing in the Chrysotoxum vernale.

Fig. 2. Location of the 30 analysed semilandmarks on the right surstylus of the male genitalia in the Chrysotoxum vernale. semi-landmarks were drawn twice to reduce statistical error. To superimpose semi-landmarks, CoordGen7.14 and an integrated Semiland module were used following a distance-minimising protocol to minimize the shape differences due to the arbitrary nature of semilandmark positions along the curve (Bookstein, 1997; Zelditch et al., 2004).

\section{Niche analysis}

This analysis was carried out for 183 specimens of morphotype A and 121 of morphotype B from Croatia, Finland, FYR Macedonia, Germany, Greece, Montenegro, Poland and Serbia. Localities with geographic coordinates were used without modification. Records with only locality names were assigned coordinates using Google Earth (Google Inc, 2013), which was also used to confirm the validity of the localities with coordinates. All localities were represented in DivaGis (v7.5) (Hijmans et al., 2012). A total of 19 Bioclim variables plus altitude (2.5 arc-minutes resolution) were generated for each locality on the basis of the WoldClim data set (Hijmans et al., 2005). Climatic profiles obtained for the two morphotypes were analysed using Principal Component
Analysis (PCA). PCA was carried out applying a normal varimax rotation of factor loadings. Only factors with an eigenvalue greater than one were considered significant. Variables with a factor loading greater than 0.8 were interpreted as significantly correlated with the correspondent factor. ANOVA and Fisher LSD post hoc test were carried out to compare the derived factor scores between the two morphotypes. A scatter plot of PCA score values was used to graphically display position of these morphotypes in environmental space.

\section{Results}

\section{Integrative taxonomy}

Morphological differences between the two identified morphotypes of C. vernale (A and B sensu Nedeljković, 2011) were small and further analyses were required to test whether they were separate taxa. To find additional differences between morphotypes A (typical C. vernale) and B (C. montanum sp. nov.), DNA, the morphometry of wings and surstyli, and ecological niches were analysed. 
A

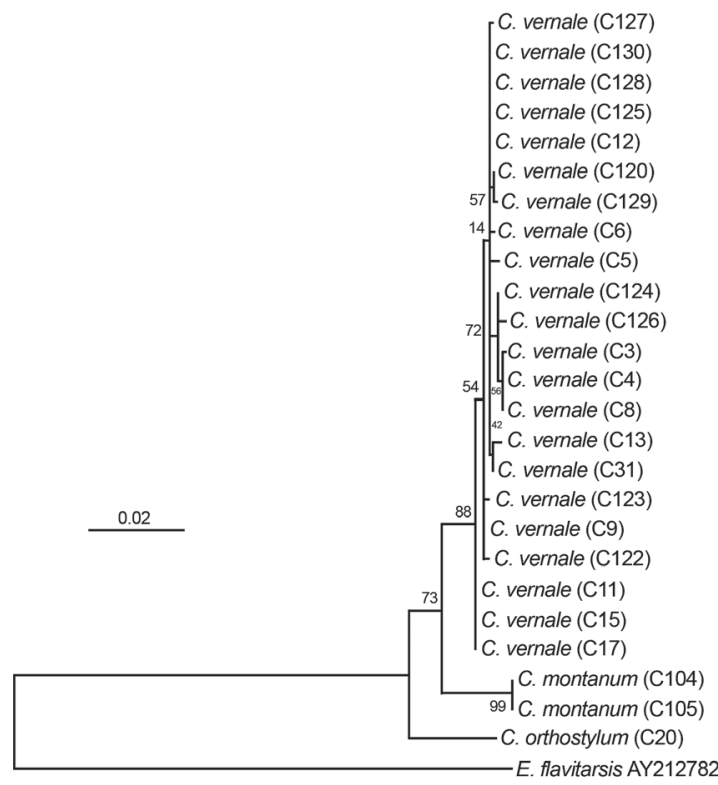

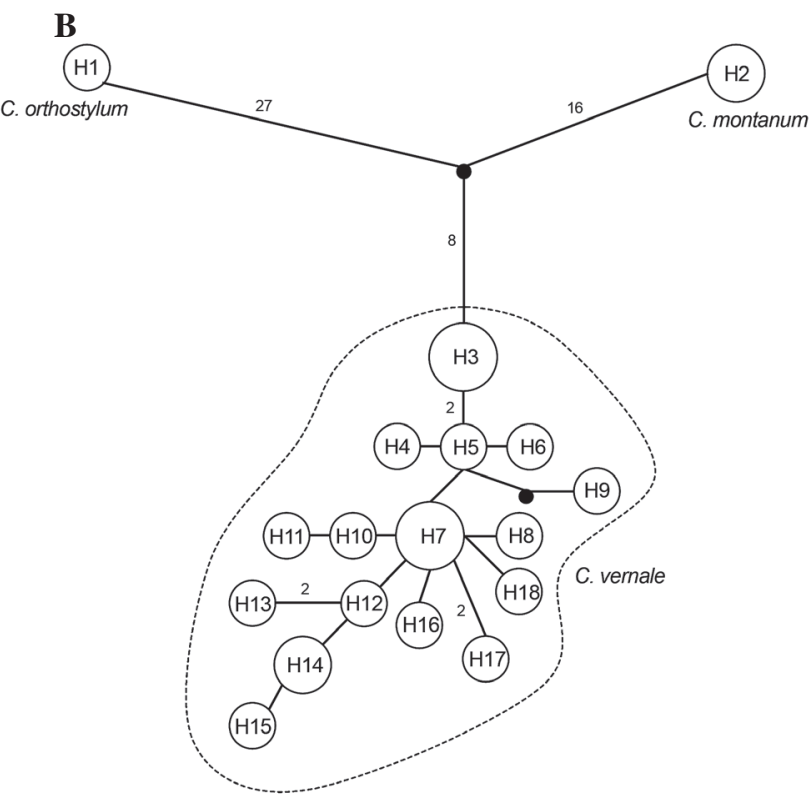

Fig. 3. Tree and network based on the merged 5' and 3' sequences of mtDNA COI. A, Maximum Likelihood (ML) tree [Bootstrap values are indicated at the nodes (1000 bootstrap replicates); outgroup, Eumerus flavitarsis]; B, Median Joining (MJ) network [Circle size corresponds to the haplotype frequency; numbers indicate the quantity of mutational steps].
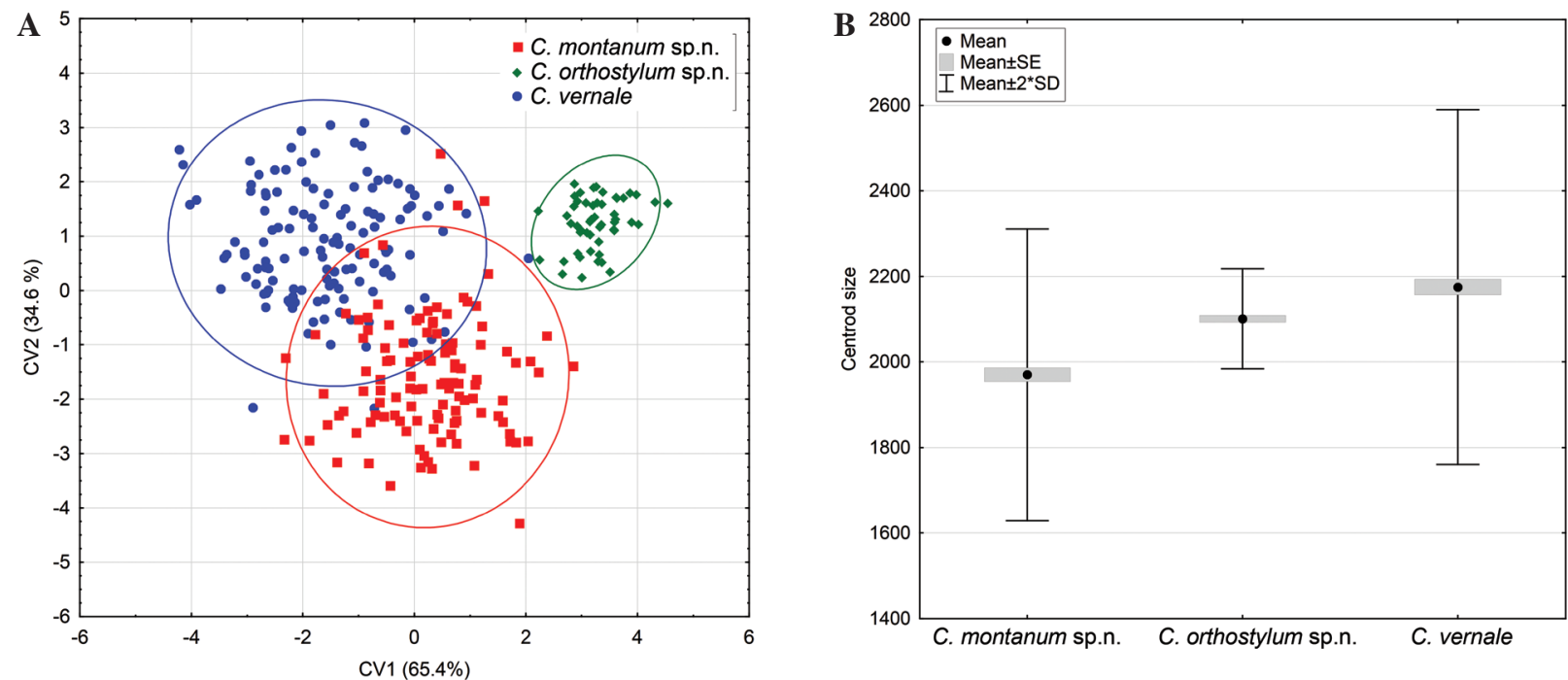

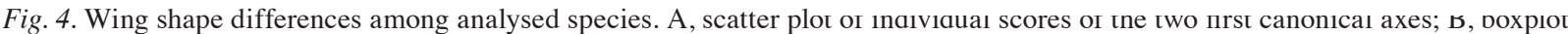
of mean centroid size.

\section{Genetic evidence}

Maximum-likelihood (ML) resolved relationships among three different Chrysotoxum species and a correspondent ML tree was obtained (Fig. 3A). ML tree based on mtDNA COI gene (Fig. 3A) revealed a clear separation of C. montanum sp. nov. from the other species (bootstrap value 99). All specimens of $C$. vernale were part of a clearly differentiated cluster and certain level of intraspecific variability was noticed. Furthermore, one sequence of an additional taxon was detected in this morphologically well-defined group (antenna 
A

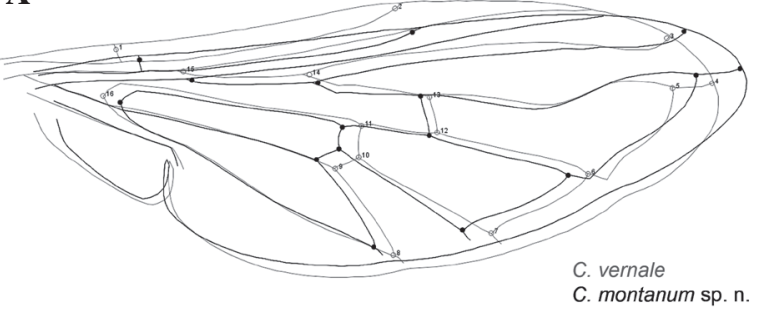

B

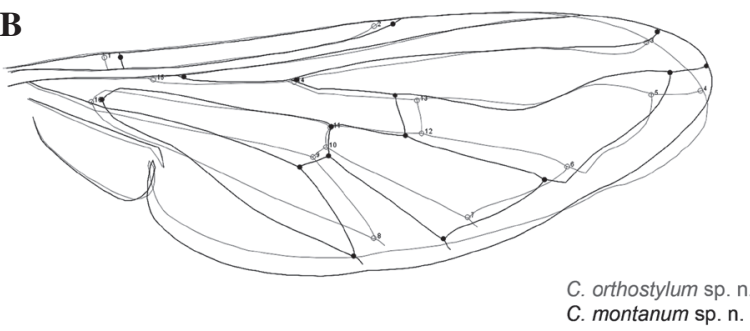

C

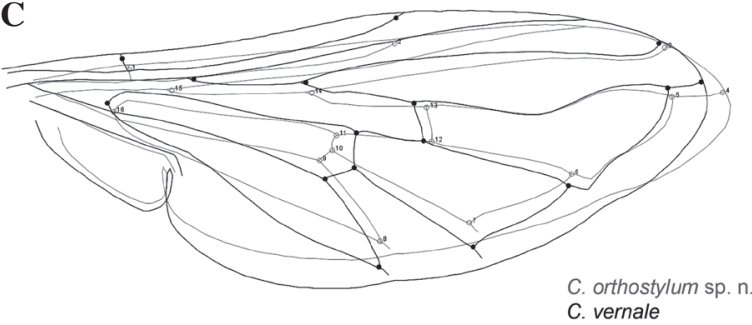

Fig. 5. Superimposed outline drawings showing wing shape differences between analysed species. A, Chrysotoxum vernale and Chrysotoxum montanum sp. nov.; B, Chrysotoxum orthostylum sp. nov. and Chrysotoxum montanum sp. nov.; C, Chrysotoxum orthostylum sp. nov. and Chrysotoxum vernale.

with the basoflagellomere shorter than the scape plus pedicel and terga with yellow fasciae not reaching the lateral margins), $C$. orthostylum sp. nov. was clearly separated as a third cluster. The MJ network suggests haplotype distribution consistent with a three cluster split in the ML tree (Fig. 3B). MtDNA COI haplotype of $C$. orthostylum is genetically the most divergent to $C$. vernale and C. montanum, with 35 and 44 mutational steps, respectively. Haplotype of mtDNA COI gene found in $C$. montanum shows 24 mutational steps to first haplotype in $C$. vernale haplogroup, and 16 steps to the first undetected haplotype in between (Fig. 3B).

\section{Geometric morphometric evidence}

Wing size and shape

The ANOVA of wing centroid size showed significant differences between $C$. vernale and C. montanum sp. nov. (males: $\mathrm{F}_{1,117}=8.99 ; \mathrm{P}<0.00331$, Tukey's post hoc test $\mathrm{p}<0.01227$; females: $\mathrm{F}_{1,117}=81.12 ; \mathrm{p}<0.00000$, Tukey's post hoc test $\mathrm{p}<0.00010$ ). ANOVA test and Tukey's post hoc test showed significant differences in wing size between $C$. orthostylum sp. nov. and $C$. vernale $\left(\mathrm{F}_{1,182}=6.69 ; \mathrm{p}<0.01045\right.$, Tukey's post hoc test $\mathrm{p}<$ 0.00969 ) and $C$. orthostylum sp. nov. and $C$. montanum sp. nov. $\left(\mathrm{F}_{1,166}=30.12 ; \mathrm{p}<0.00000\right.$, Tukey's post hoc test $\mathrm{p}<0.00000)$. Chrysotoxum vernale has larger wings than $C$. montanum sp. nov. and C. orthostylum sp. nov. (Fig. 4B).

Differences in wing shape between $C$. vernale and $C$. montanum sp. nov. were highly significant using MANOVA (males: Wilks' Lambda $=0.25314 ; \mathrm{F}_{28,95}=$ 10.01020; $\mathrm{p}<0.00000$; females: Wilks' Lambda $=$ 04.40454; $\left.\mathrm{F}_{28,90}=4.73120 ; \mathrm{p}<0.00000\right)$. Highly significant differences in wing shape were also shown between C. orthostylum sp. nov. and C. vernale (Wilks' Lambda $\left.=0.15640 ; \mathrm{F}_{28.155}=29.85972 ; \mathrm{p}<0.00000\right)$, and C. orthostylum sp. nov. and C. montanum sp. nov. (Wilks' Lamb$\mathrm{da}=0.16331 ; \mathrm{F}_{28,139}=25.43285 ; \mathrm{p}<0.00000$ ).

DA correctly classified the material studied in accordance with the three defined species. The overall classification success of the DA was $92.95 \%$ which indicates wing shape is a reliable predictor of interspecific discrimination. Of the 249 digitalisations, only 21 were misclassified. Canonical variate analysis conducted on shape variables gave two highly significant axes. The first canonical axis (CV1), with $65.4 \%$ of total variation, separated $C$. vernale from $C$. orthostylum sp. nov. (Wilks' Lambda $=0.09515 ; \chi^{2}=662.18 ; \mathrm{p}<0.00000$ ). The second canonical axis (CV2), with $34.6 \%$ of total variation, separated $C$. vernale and $C$. orthostylum sp. nov. from $C$. montanum sp. nov. (Wilks' Lambda $=$ $0.38388 ; \chi^{2}=269.52 ; \mathrm{p}<0.00000$ ) (Fig. 4A). The superimposed outline drawings showing major wing deformations between $C$. vernale and C. montanum sp. nov. occur in the central and distal part of wing and are associated with landmarks 2, 4, 5 and 9-11 (Fig. 5A). Major differences in wing shape were found in the central part of the wing (landmarks 2, 7-11) of C. orthostylum sp. nov. and C. vernale (Fig. 5C), and in the central (landmarks 7, 8, 12 and 13) and apical parts in C. orthostylum sp. nov. and C. montanum sp. nov. (landmarks 4 and 5) (Fig. 5B). Chrysotoxum vernale has wider wings, while C. orthostylum sp. nov. longer wings.

Surstylus shape

Significant differences in surstylus shape between $C$. vernale and $C$. montanum sp. nov. were found with 
Table 1. Principal component analysis (PCA) of 19 Bioclim variables plus altitude for $C$. montanum sp. nov. and $C$. vernale. Significant factor loadings are printed in bold.

\begin{tabular}{|c|c|c|c|}
\hline \multirow[t]{2}{*}{ Variables } & \multicolumn{3}{|c|}{ Factor Loadings } \\
\hline & PC1 & PC2 & PC3 \\
\hline Altitude & -0.54 & -0.81 & 0.04 \\
\hline BIO1 = Annual Mean Temperature & 0.24 & 0.94 & 0.17 \\
\hline $\mathrm{BIO} 2=$ Mean Diurnal Range (Mean of monthly $(\max$ temp $-\min$ temp)) & 0.46 & 0.17 & 0.84 \\
\hline $\mathrm{BIO} 3=$ Isothermality $(\mathrm{BIO} 2 / \mathrm{BIO} 7)(* 100)$ & 0.02 & 0.05 & 0.90 \\
\hline BIO4 = Temperature Seasonality (standard deviation $* 100)$ & 0.83 & 0.22 & 0.24 \\
\hline BIO5 = Max Temperature of Warmest Month & 0.38 & 0.85 & 0.33 \\
\hline BIO6 = Min Temperature of Coldest Month & 0.01 & 0.98 & 0.00 \\
\hline BIO7 = Temperature Annual Range (BIO5-BIO6) & 0.69 & 0.19 & 0.60 \\
\hline BIO8 = Mean Temperature of Wettest Quarter & 0.77 & 0.47 & -0.18 \\
\hline BIO9 = Mean Temperature of Driest Quarter & -0.70 & 0.46 & 0.35 \\
\hline BIO10 = Mean Temperature of Warmest Quarter & 0.35 & 0.91 & 0.18 \\
\hline BIO11 = Mean Temperature of Coldest Quarter & 0.05 & 0.98 & 0.11 \\
\hline BIO12 = Annual Precipitation & -0.89 & -0.35 & -0.23 \\
\hline BIO13 = Precipitation of Wettest Month & -0.84 & -0.14 & -0.30 \\
\hline BIO14 = Precipitation of Driest Month & -0.74 & -0.55 & -0.25 \\
\hline BIO15 = Precipitation Seasonality (Coefficient of Variation) & 0.51 & 0.59 & 0.04 \\
\hline BIO16 = Precipitation of Wettest Quarter & -0.84 & -0.17 & -0.29 \\
\hline BIO17 = Precipitation of Driest Quarter & -0.80 & -0.49 & -0.25 \\
\hline BIO18 = Precipitation of Warmest Quarter & -0.38 & -0.61 & -0.51 \\
\hline BIO19 = Precipitation of Coldest Quarter & -0.94 & -0.21 & -0.08 \\
\hline Eigenvalue & 12.21 & 3.48 & 1.96 \\
\hline Variance explained $(\%)$ & 61.0 & 17.4 & 9.8 \\
\hline
\end{tabular}

MANOVA $\left(\mathrm{F}_{1,91}=32.3 ; \mathrm{p}<0.00099\right)$ and canonical analyses (axis 1: Wilks' Lambda $=0.0425 ; \chi^{2}=199.02$; $\mathrm{p}<0.00099$ ). Discriminant analysis of surstylus shape classified correctly $C$. vernale and $C$. montanum sp. nov. with $100 \%$ overall classification success. This high rate of overall classification success indicates that surstylus shape is a reliable predictor of interspecific discrimination. Representation of the thin-plate spline deformation of surstyli showed differences in surstylus shape between C. vernale and C. montanum sp. nov. (Fig. 6).

Ecological evidence

The PCA reduces the Bioclim variables (Table 1) to three PCs with eigenvalue $\geq 1.88 \%$ of the variation. Separation among species were statistically significant along PC1 and PC2 (ANOVA, PC1: $\mathrm{F}_{1,302}=141.26$; $\mathrm{p}<$ 0.00000 , Fisher LSD post hoc test $p<0.00000$; PC2: $\mathrm{F}_{1,302}=155.27 ; \mathrm{p}<0.00000$, Fisher LSD post hoc test $\mathrm{p}$ $<0.00000)$, but not along PC3 $\left(\mathrm{F}_{1,302}=1.90\right.$; $\mathrm{p}<$ 0.168397). Because of this, PC3 was excluded in the interpretation of results. The precipitation-related PC1 explained $61 \%$ of the total variation, while the tem- perature- and altitude-related PC2 explained 17\% of the total variation (Table 1). The scatter plot of PC1 against PC2 illustrated a clear niche separation between $C$. vernale and C. montanum sp. nov. Chrysotoxum vernale occurs across a wide temperature range, precipitation and altitude (Fig. 7), while C.montanum sp. nov. occurs in a much narrower range of temperatures. Chrysotoxum montanum sp. nov. occurs only at high altitudes with high precipitation, and its distribution is strongly influenced by the precipitation in the coldest and wettest quarters of the year (BIO19, BIO12, $\mathrm{BIO16}$ and $\mathrm{BIO13).}$

\section{Discussion}

In this study two new species of the $C$. vernale species complex are described, $C$. montanum sp. nov. and $C$. orthostylum sp. nov., and $C$. vernale is re-defined. $C$. vernale and $C$. montanum sp. nov. are similar species, while $C$. orthostylum sp. nov. can be clearly separated from $C$. vernale and $C$. montanum sp. nov. based on morphology. An integrative approach (traditional 


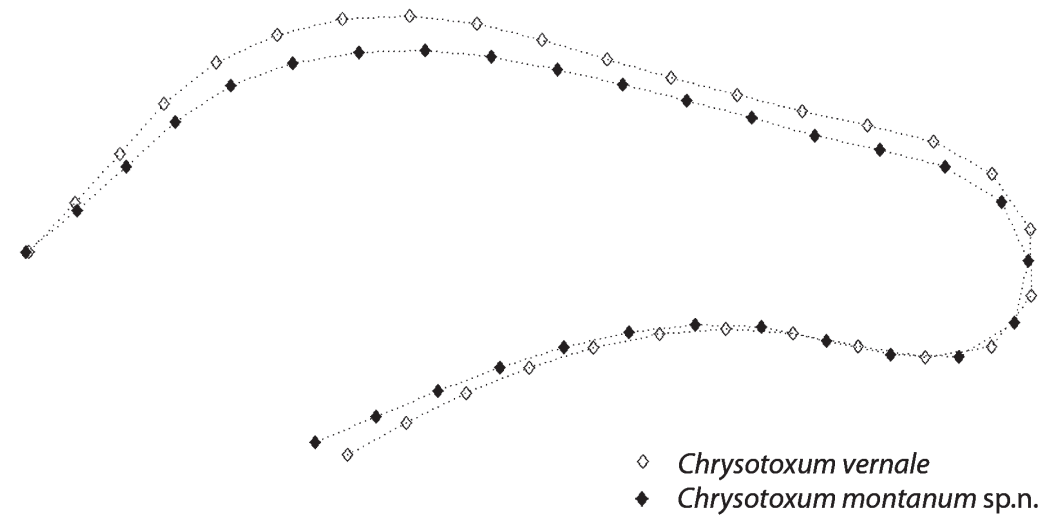

Fig. 6. Superimposed outline drawings showing surstylus shape differences between Chrysotoxum montanum sp. nov. and Chrysotoxum vernale.

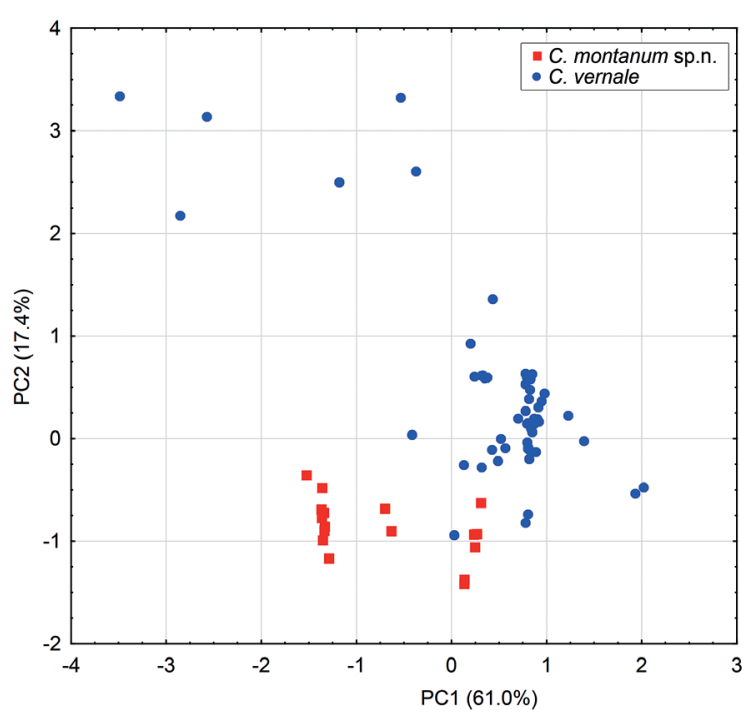

Fig. 7. Scatter plot of factor loadings of two PC scores showing the positions of Chrysotoxum montanum sp. nov. and Chrysotoxum vernale in the environmental space.

morphology, genetics, geometric morphometry, ecology) was used to distinguish C. montanum sp. nov. from the similar $C$. vernale.

The main morphological character distinguishing C. montanum sp. nov. from C. vernale is the colour of pile on face, occiput, scutum and scutellum in males which are black in C. montanum sp. nov. (Fig. 8B) and yellow in $C$. vernale (Fig. 8A). In many syrphid species such as Episyrphus balteatus (De Geer, 1776) and Eupeodes corollae (Fabricius, 1794) colour differences are not a fixed character and depend on the period of adult emergence and on the temperature experienced by the pupa (Dušek and Láska, 1974). It is also known that within certain genera, spring emerging species have overall body colours darker than those of the lighter summer-emerging species (Rotheray and Gilbert, 2011). Genetic, morphometric and ecological evidence obtained here is congruent and indicates that differences between morphotypes $\mathrm{A}$ and $\mathrm{B}$ of $C$. vernale (sensu Nedeljković, 2011) are explained by their belonging to different taxa, C. montanum sp. nov. (B) and $C$. vernale (A).

The European Chrysotoxum species can be grouped according to the proportional length of the basoflagellomere: species with basoflagellomere shorter than scape and pedicel together, Chrysotoxum bicinctum (Linnaeus, 1758), Chrysotoxum elegans Loew, 1841, Chrysotoxum festivum (Linnaeus, 1758), Chrysotoxum gracile Becker, 1921, Chrysotoxum lineare (Zetterstedt, 1819), C. montanum sp. nov., Chrysotoxum octomaculatum Curtis, 1837, C. orthostylum sp. nov., Chrysotoxum parmense Rondani, 1845, Chrysotoxum tomentosum Giglio-Tos, 1890, C. vernale and Chrysotoxum verralli Collin, 1940; species with basoflagellomere longer than scape and pedicel together, Chrysotoxum arcuatum (Linnaeus, 1758), Chrysotoxum cisalpinum Rondani, 1845, Chrysotoxum cautum (Harris, 1776), Chrysotoxum fasciolatum (De Geer, 1776) and Chrysotoxum intermedium Meigen, 1822. Within the group with a relatively short basoflagellomere, Masseti et al. (2006) defined the morphological festivum group, C. bicinctum, C. festivum, C. elegans, C. octomaculatum, C.parmense and C. vernale, excluding characters such as the colour of femur and lateral margin of terga 3 and 4. Based on morphology, C. tomentosum, $C$. montanum sp. nov., and $C$. orthostylum sp. nov. are likely to belong to the festivum group (sensu Masseti et al., 2006). These three species have the yellow fasciae on terga 3 and 4 not reaching the lateral margin of the tergum, but the festivum group (sensu Masseti et al., 
2006) includes some species with yellow fasciae reaching the lateral margin. Further morphological and molecular analyses are required to access the concept of a festivum group.

Regarding the genetic results of the present study $C$. montanum sp. nov. was grouped in a separate cluster of the ML tree (Fig. 3A). Analysis showed that COI sequences of mtDNA separated $C$. montanum sp. nov. and $C$. vernale. The species $C$. montanum sp. nov. clustered in a clearly independent position both in the ML tree (Fig. 3A) and MJ network (Fig. 3B). The species C. orthostylum sp. nov. also clustered in an independent position in the ML tree (Fig. 3A), and showed the greatest genetic divergence from $C$. vernale and $C$. montanum in the MJ network (Fig. 3B). Only one fresh specimen of $C$. orthostylum sp. nov. was available for molecular study and further specimens must be analysed to determine the phylogenetic position of C. orthostylum sp. nov.

Prior to the present study, the COI region had already been shown as a useful taxonomic tool; for instance, it proved informative for separating C. cautum from $C$. bicinctum, and also $C$. parmense and $C$. fasciolatum, but failed in delimiting species borders between C. festivum and C. elegans (Masseti et al., 2006). Our preliminary investigation on 3 ' fragment of COI gene variation in the genus Chrysotoxum (Veličković et al., 2012) showed that the implementation of COI as a molecular marker was found insufficiently precise to identify the differences within vernale complex (morphotypes $C$. vernale A, $C$. vernale B) and festivum complex (morphotypes $C$. festivum A and C. festivum B, and C. elegans). Following these conclusions Nedeljković et al. (2013) have used ITS2 as a marker of choice differences have been found between C.festivum and C.elegans. In the present study we have tested our second idea that the combination of both 5' and 3' sequences of COI gene will generate sufficient level of divergence for delimiting putative cryptic species. We have shown that COI was sufficient to separate $C$. montanum sp. nov. from the simi$\operatorname{lar} C$. vernale. One of the conclusions could be that there is no a priori chosen single marker that could successfully solve taxonomic problems in Syrphidae. Results of this study show that the COI gene has justified its reputation of a stable barcoding marker, but there have been cases within the genus Chrysotoxum (Masetti et al., 2006), and even in other syrphid genera when the mtDNA COI failed to work well and the sequence divergence was relatively low, and even invariant (Milankov et al., 2008, 2009; Francuski et al.,
2011, Haarto and Ståhls, 2014). Therefore an integrative taxonomy approach provides a better method to delimit closely related hoverfly species.

Significant differences in wing size and shape between $C$. montanum sp. nov., C. vernale and $C$. orthostylum were detected (Fig. 5A). Inconspicuous but statistically significant differences in surstylar shape between $C$. montanum sp. nov. and C. vernale were also revealed with a geometric morphometric analysis; this is the second example after that of Nedeljkovic et al. (2013) in which geometric morphometry of genitalia has successfully contributed to the separation of cryptic syrphid species. In addition, niche divergence analysis reveals that $C$. montanum sp. nov. is more specialised than C. vernale. Chrysotoxum montanum sp. nov. occurs only at high altitudes with high precipitation, while $C$. vernale is able to thrive in a wider range of environmental conditions of temperature, precipitation and altitude. The sympatric (e.g. in FYR Macedonia, Golema poljana) and synchronic (early May to mid-August) distributions of C. montanum sp. nov. and $C$. vernale also support their taxonomic separation.

Animal diversity in the Balkan Peninsula is exceptionally rich and includes many endemic and relict species (Savić, 2008). In this region, insects have experienced an extraordinary adaptive radiation as a result of glacial and inter-glacial periods, particularly in Coleoptera (Mesarosh, 1996), Lepidoptera (Jakšić, 1998) and Diptera, Syrphidae (Vujić et al., 2001). In the present study, integrative taxonomy is confirmed as a useful tool to better understand the entomological diversity in the Balkans and consequently improve the basic knowledge required for species conservation in this exceptional place.

\section{Acknowledgements}

We thank Dr Joachim Ziegler (ZHMB) for arranging the loan of specimens, as well as Peter Sehnal and Dr Menno Reemer for enabling access to the NHMW and RMNH collections respectively. Thanks to Dr Luca Bartolozzi (LSF) for making pictures of type specimens. Thanks to Sven Marotzke (ZHMB) for useful information about Loew's type collection. We kindly thank Dieter Doczkal for taxonomic advice and to allowing us to examine material in his private collection (DD). Thanks to Dr Gunilla Ståhls (MZH) and Dr Axel Ssymank (AS) for material provided. Thanks to the members of the Palynology Laboratory, University of Novi Sad (Serbia) for enabling us to use their technological facilities. Dr Graham Rotheray (NMS) kindly revised the English of this manuscript. We thank an anonymous referee who provided useful comments on the manuscript. Financial support was provided by the Serbian Ministry of Education, Science and Technological Development (projects 
OI173002 and III43002), the Provincial Secretariat for Science and Technological Development (project 'Genetic resources of agro-ecosystems in Vojvodina and sustainable agriculture'), the Transnational Access to Research Infrastructures activity in the FP7 of the EC (ExpeER project, TA visit 'STEPS') and the FP7 EU project, Innosense.

\section{References}

Anderson EL. 1954. Hoyer's Solution as a Rapid Permanent Mounting Medium for Bryophytes. The Bryologist 3: 242-244.

Arnqvist G, Mårtensson T. 1998. Measurement error in geometric morphometrics: empirical strategies to assess and reduce its impact on measures of shape. Acta Zoologica Academiae Scientiarum Hungaricae 44: 73-96.

Bandelt HJ, Forster P, Röhl A. 1999. Median-joining networks for inferring intraspecific phylogenies. Molecular Biology and Evolution 16: 37-48.

Birdsall K, Zimmerman E, Teeter K, Gibson G. 2000. Genetic variation for the positioning of wing veins in Drosophila melanogaster. Evolution and Development 2: 16-24.

Bitner-Mathé BC, Klaczko BL. 1999. Size and shape heritability in natural populations of Drosophila mediopunctata: temporal and microgeographical variation. Genetica 105: $35-42$.

Bond JE, Stockman AK. 2008. An integrative method for delimiting cohesion species: finding the population-species interface in a group of Californian trapdoor spiders with extreme genetic divergence and geographic structuring. Systematic Biology 4: 628-646.

Bookstein FL. 1991. Morphometrics tools for landmark data. Cambrigde: Cambridge University Press.

Bookstein FL. 1997. Landmark methods for forms without landmarks: morphometrics of group differences in outline shape. Medical Image Analysis 1: 225-243.

Chen H, Rangasamy M, Tan SY, Wang H, Siegfried BD. 2010. Evaluation of Five Methods for Total DNA Extraction from Western Corn Rootworm Beetles. PLoS ONE 5: e11963.

Dayrat B. 2005. Towards integrative taxonomy. Biological Journal of the Linnean Society 85: 407-415.

Dušek J, Láska P. 1974. Influence of temperature during pupal development on the colour of syrphid adults (Syrphidae, Diptera). Facultatis scientiarum naturalium universitatis purkynianae bruennsis, Biologia 43: 77-81.

Folmer O, Black M, Hoeh W. 1994. DNA primers for amplification of mitochondrial cytochrome c oxidase subunit I from diverse metazoan invertebrates. Molecular Marine Biology and Biotechnology 3: 294-299.

Francuski Lj, Vujić A, Kovačević A, Ludoški J, Milankov V. 2009. Identification of the species of the Cheilosia variabilis group (Diptera, Syrphidae) from the Balkan Peninsula using wing geometric morphometrics, with the revision of status of C. melanopa redi Vujić, 1996. Contributions to Zoology 78: $129-140$.

Francuski Lj, Ludoški J, Vujić A, Milankov V. 2011. Phenotypic evidence for hidden biodiversity in the Merodon aureus group (Diptera, Syrphidae) on the Balkan Peninsula: conservation implication. Journal of Insect Conservation 15: 379-388.

Funk DJ, Nosil P, Etges WJ. 2006. Ecological divergence exhibits consistently positive associations with reproductive isola- tion across disparate taxa. Proceedings of the National Academy of Sciences of the United States of America 103: 3209-3213.

Giglio-Tos E. 1890. Le specie europee del genere Chrysotoxum Meig. Atti della R. Accademia delle Scienze di Torino 26: 134-165.

Google Inc. 2013. Google Earth. Mountain View, CA.

Haarto A, Ståhls G. 2014. When mtDNA COI is misleading: congruent signal of ITS2 molecular marker and morphology for North European Melanostoma Schiner, 1860 (Diptera, Syrphidae). Zookeys 431: 93-134.

Hall TA. 1999. BioEdit: a user-friendly biological sequence alignment editor and analysis program for Windows 95/98/ NT. Nucleic Acids Symposia Ser 41: 95-98.

Hijmans RJ, Cameron SE, Parra JL, Jones PG, Jarvis A. 2005. Very high resolution interpolated climate surfaces for global land areas. International Journal of Climatology 25: 19651978.

Hijmans RJ, Guarino L, Mathur P. 2012. DIVA-GIS. Vsn. 7.5. A geographic information system for the analysis of species distribution data. (available at: http://www.diva-gis.org).

Jakšić P. 1998. Dnevni leptiri Balkanskog poluostrva. Bionet 8: 22-24.

Klingenberg CP. 2011. MORPHOJ: an integrated software package for geometric Morphometrics. Ver.2. 0. [Computer software and manual]. Molecular Ecology Resources 11: 353-357.

Locke M, Skevington J. 2013. Revison of Nearctic Dasysyrphus Enderlein (Diptera: Syrphidae). Zootaxa 3660: 1-80.

Ludoški J, Francuski Lj, Vujić A, Milankov V. 2008. The Cheilosia canicularis group (Diptera: Syrphidae): species delimitation and evolutionary relationships based on wing geometric morphometrics. Zootaxa 1825: 40-50.

Marcos-García MA, Vujić A, Ricarte A, Ståhls G. 2011. Towards an integrated taxonomy of the Merodon equestris complex (Diptera: Syrphidae) including description of a new species, with additional data on Iberian Merodon. Canadian Entomologist 143: 332-348.

Masetti A, Luchetti A, Sommaggio D, Burgio G, Mantovani B. 2006. Phylogeny of Chrysotoxum species (Diptera: Syrphidae) inferred from morphological and molecular characters. European Journal of Entomology 103: 459-467.

Mesarosh G. 1996. Mechanisms and patterns of evolutionary divergence in high-altitude weevils from mountains of central parts of the Balkan Peninsula. Global Biodiversity Research in Europe, International Senckenberg Conference, Abstract Volume: 53-54. Frankfurt a/M., Germany.

Milankov V, Ståhls G, Stamenković J, Vujić A. 2008. Genetic diversity of populations of Merodon aureus and M. cinereus species complexes (Diptera, Syrphidae): integrative taxonomy and implications for conservation priorities on the Balkan Peninsula. Conservation Genetics 9: 1125-1137.

Milankov V, Ludoški J, Ståhls G, Stamenković J, Vujić A. 2009. High molecular and phenotypic diversity in the Merodon avidus complex (Diptera, Syrphidae): cryptic speciation in a diverse insect taxon. Zoological Journal of the Linnean Society 155: 819-833.

Nedeljković Z. 2011. Taxonomic analyses of the species from the subfamily Syrphinae (Diptera: Syrphidae) in Serbia. PhD Thesis, Novi Sad University (Serbia). [In Serbian]

Nedeljković Z, Ačanski J, Vujić A, Obreht D, Đan M, Ståhls G, Radenković S. 2013. Taxonomy of Chrysotoxum festivum 
Linnaeus, 1758 (Diptera: Syrphidae) - an integrative approach. Zoological Journal of the Linnean Society 169: 84-102.

Nosil P, Harmon LJ, Seehausen O. 2009. Ecological explanations for (incomplete) speciation. Trends in Ecology and Evolution 24: 145-156.

Palma G. 1863. Ditteri della fauna napolitana. Annali dell' Accademia degli Aspiranti Naturalisti 3: 37-66.

Peck LV. 1988. Syrphidae. Pp. 1-327 in: Soos A, Papp L, eds. Catalogue of Palaearctic Diptera. Budapest: Akademia Kiado.

Radenković S, Vujić A, Ståhls G, Pérez-Bañón C, Rojo S, Petanidou T, Šimić S. 2011. Three new cryptic species of the genus Merodon Meigen (Diptera: Syrphidae) from the island of Lesvos (Greece). Zootaxa 2735: 35-56.

Rohlf FJ. 2006. TpsDig - Digitize landmarks and outlines. Ver. 2.05. [Computer software and manual]. Department of Ecology and Evolution, State University of New York at Stony Brook.

Rohlf FJ, Slice DE. 1990. Extensions of the Procrustes method for the optimal superimposition of landmarks. Systematic Zoology 39: 40-59.

Rotheray GE. 1994. Colour guide to hoverfly larvae (Diptera, Syrphidae) in Britain and Europe. Dipterists Digest 9: 1-156.

Rotheray GE, Gilbert F. 2011. The Natural History of Hoverflies. Ceredigion: Forrest text.

Sang-Wook S, Ho-Yeon H. 2013. Clarification of previously confused Chrysotoxum sapporense and Chrysotoxum graciosum (Insecta: Diptera: Syrphidae) in East Asia based on morphological and molecular data. Animal Cells and Systems 17: 277-289.

Savić IR. 2008. Diversification of the Balkan fauna: its origin, historical development and present status. Pp. 57-78 in: Ćurčić B, Makarov SE, Dimitrijević RN, eds. Advances in Arachnology and Developmental Biology. Inst. Zool., Belgrade; BAS, Sofia; Fac. Life Sci., Vienna; SASA, Belgrade $\&$ UNESCO MAB Serbia.

Sheets HD. 2012. IMP software series. [Computer software and manual]. Buffalo, New York: Canisius College.

Simon C, Frati F, Beckenbach A, Crespi B, Liu H, Flook P. 1994. Evolution, weighting and phylogenetic utility of mitochondrial gene sequences and a compilation of conserved polymerase chain reaction primers. Annual Entomological Society of America 87: 651-701.

Skevington J, Thompson C. 2012. Review of New World Sericomyia (Diptera: Syrphidae), including description of a new species. Canadian Entomologist 144: 216-247.

Sommaggio D. 2001. The species of the genus Chrysotoxum Meigen, 1822 (Diptera, Syrphidae) described by Giglio Tos. Bollettino del Museo Regionale di Scienze Naturali, Torino 1: 115-126.

Speight MCD. 2013. Species accounts of European Syrphidae (Diptera) 2013. Syrph the Net, the database of European Syrphidae. Vol.72, Dublin: Syrph the Net publications.

StatSoft Inc. 2012. STATISTICA - data analysis software sys-

\section{Online supplementary information}

S1. List of material examined.

$S 2$. List of specimens used for molecular analyses. tem. Ver. 12. [Computer software]. USA: StatSoft.

Tamura K, Stecher G, Peterson D, Filipski A, Kumar S. 2013. MEGA6: Molecular Evolutionary Genetics Analysis version 6.0. Molecular Biology and Evolution 30: 2725-2729.

Thompson FC, Rotheray G. 1998. Family Syrphidae. Pp. 81-139 in: Papp L, Darvas B, eds, Contributions to a Manual of Palaearctic Diptera 3. Budapest: Science Herald.

Thompson FC. 1999. A key to the genera of the flower flies of the Neotropical Region including the descriptions of genera and species and a glossary of taxonomic terms. Contributions on Entomology, International 3: 319-378.

Thompson JD, Higgins DG, Gibson TJ. 1994. Cluskal W: improving the sensitivity of progressive multiple sequence alignment through sequence weighting, position-specific gap penalties and weigh matrix choice. Nucleic Acids Research 22: 4673-4680.

Veličković N, Obreht D, Đan M, Kočiš Tubić N, Vujić A. 2012. Cytochrome oxidase I gene variation in genus Chrysotoxum (Diptera, Syrphidae). Pp. 63-68 in: Sabin I, ed., Proceedings of the XIVth International Symposium 'Young People and Multidisciplinary Research', Timişoara. Timisoara, Romania: Editura Politechnica.

Violovitsh NA. 1974. A review of the palaearctic species of the genus Chrysotoxum Mg. (Diptera, Syrphidae). Энтомологическое обозрение (Entomological Review) 53: $196-217$.

Vockeroth JR. 1969. A revision of the genera of the Syrphini (Diptera: Syrphidae). Pp. 1-176 in: Pielou DP, ed., Memoirs of the Entomological Society of Canada No. 62. Ottawa: The Entomological Society of Canada.

Vujić A, Šimić S, Radenković S. 2001. Endangered species of hoverflies (Diptera: Syrphidae) on the Balkan Peninsula. Acta entomologica serbica 5: 93-105.

Vujić A, Radenković S, Ståhls G, Ačanski J, Stefanović A, Veselić S, Andrić A, Hayat R. 2012. Systematics and taxonomy of the ruficornis group of genus Merodon Meigen (Diptera: Syrphidae). Systematic Entomology 37: 578-602.

Vujić A, Ståhls G, Ačanski J, Bartsch H, Bygebjerg R, Stefanović A. 2013. Systematics of Pipizini and taxonomy of European Pipiza Fallén: molecular and morphological evidence (Diptera, Syrphidae). Zoologica Scripta 42: 288-305.

Wooten JA, Gibbs HL. 2012. Niche divergence and lineage diversification among closely related Sistrurus rattlesnakes. Journal of evolutionary biology 25: 317-328.

Zelditch ML, Swiderski DL, Sheets HD, Fink WL. 2004. Geometric Morphometrics for Biologists: a primer. London: Elsevier Academic Press.

Zhu G, Liu G, Bu W, Lis JA. 2013. Geographic distribution and niche divergence of two stinkbugs, Parastrachia japonensis and Parastrachia nagaensis. Journal of Insect Science 13: 102.

Received: 19 December 2014

Revised and accepted: 7 July 2015

Published online: 30 October 2015

Editor: J.C. Biesmeijer 


\section{Appendix}

\section{Descriptions of new species}

Two new species of the vernale complex are described in the present study, and the species $C$. vernale is redefined. The three studied species shared an antenna with the basoflagellomere shorter than scape and pedicel together and abdominal terga with yellow fasciae not reaching the lateral margins.

Family Syrphidae

Genus Chrysotoxum Meigen, 1803

Chrysotoxum montanum Nedeljković \& Vujić sp. nov. (= morphotype B sensu Nedeljković, 2011)

(Figs 8b, 11a, 13a)

Holotype male, SERBIA, Kopaonik, Klisura Samokovske reke-mešano, 16.vi.2012, leg. A. Vujić (G1530, C104).

Paratypes. AUSTRIA: 1m, Frankenfels, 6/78, Bgst, (S11479), (NHMW); BOSNIA \& HERZEGOVINA: 2m, Igman-Bjelašnica, 26.VI.1989. (S11301, S11302); 1m, Jahorina, 26.VI.1989. (S11300); MONTENEGRO: Durmitor, 1m, Crepulj poljana, 4.VII.1991. (S11361), 1m, Crno jezero, 21.VI.1983. (S11324), 3m, do Male Karlice, 13.VII.1981. (S11358, S11359, S11360), 3m, do Zminjeg jezera, 3.VII.1981. (S11352, S11353, S11354), 3f, Ivan Do, 16.VIII.1984. (S11328), 27.VI.1993. (S11329, S11330); 1m, 1f, Jablan jezero, 20.VII.1995. (S11346, S11347); 4m, ka Jablan jezeru, 7.VII.1991. (S11342, S11343, S11344, S11345); 10m, ka Savinom kuku, 11.VII.1981. (S11305, S11306, S11307, S11308, S11311, S11313, S11309, S11310, S11312, S11314), 4m, Kanjon Sušice, 6.VII.1994. (S11337, S11341), 9. VII.1991. (S11338, S11327), 8m, Mlinski potok, 3. VII.1991. (S11321， S11322， S11323), 6.VII.1983. (S11315, S11316), 22.VI.1985. (S11317, S11318, S11319), 2m, 2f, Motički gaj, 9-10.VII.1983. (S11320, S11355, S11356, S11357), 1m, 1f, Otoka Crnog jezera, 24. VI.1983. (S11325, S11326) 1f, Pirlitor-Tara, 25.VI.1983. (S11363), 1m, Pitomine, 1.VII.1983. (S11362), 1f, Razvršje, 21.VIII.1984. (S11364), 2m, Sušica, 28. VI.1985. (S11334, S11335), 2m, 1f, Sušica-Skakala, 2526.VI.1997. (S11366), 29.VI.1993. (S11339, S11340), 4m, Sušičko jezero, 25.VI.1985. (S11331, S11332, S11333), 25-27.VI.1986. (S11336), 5m, 2f, Sušičko jezero-Sastavci, 2.VI.1998. (S11365, S11370), 20.VI.1998. (S11367, S11368, S11369, S11371, S11372), 1m, Tepca, 6.VII.1983. (S11348), 3m, Tepca-kanjon Tare, 21.VI. 1983. (S11349, S11350, S11351); SERBIA: Kopaonik, 1m, 1f, Bačište, 4.VII.1986. (S06423, S06321), 2m, do Jablanove ravni, 23.VI.1991. (S06416, S06417), 2m, Duboka reka, 6.VII.1986. (S06420), 18.VII.1986. (S06421), 1f, Jablanova ravan, 20.V.1986. (S06390), 2m, Jasle-Jablanova ravan, 14.VI.1986. (S11444, S06418), 1m, 1f, Jasle-Čukara, 20.VI.1996. (S06415), 23.V.1993. (S06419), 1m, Kadijevac, 21.VI.1991. (S06422), 27m, 1f, Samokovska reka, 5.VII.1986. (S06402), 14.VIII.1997. (S06389), 16.VI.1986. (S06395, S06396, S06409, S06406, S06388, S06410, S06397, S06398, S06399, S06401, S06400, S06394), 19.VI.1996. (S06392, S06393), 21.VI.1991. (S06403), 22.V.1986. (S06407), 22.VI.1991. (S06404, S06405, S06386, S06411, S06412), 24.V.1992. (S06413, S06387), 24.V.1993. (S06391), 27.V.1994. (S06406, S06414), 1f, Treska - bukva, 17.VII.1985. (S06425), 1f, Velika reka, 14.VI.1986. (S06424), 1m, Klisura Samokovske rekemešano, 16.VI.2012. (G1531/C105); Prokletije, 1m, ka Volušnici, 29.VII.1994. (S06385); Šar planina, 1m, Muržica, 12.VII.1996.(S06426); 3m, Ošljak, 29.VI.1988. (S06427, S06428, S11445).

Diagnosis. Medium to large species $(15-17 \mathrm{~mm}, \mathrm{n}=$ $10) ; \mathrm{r}=1: 0.8: 1.8$; vertical and frontal triangles with black pile; scutum with black pile (Fig. 8B); katepisternum completely black (Fig. 9C) or with a very small yellow macula; scutellum with long black pile; male genitalia very similar to that in $C$. vernale; surstylus 1.3 times longer than hypandrium (excluding superior lobes and aedeagus); epandrium plus surstylus 1.2-1.3 times longer than hypandrium (excluding superior lobes and aedeagus); in female frons black, with two triangular pollinose maculae. Chrysotoxum montanum has longer wings than C. vernale. Chrysotoxum montanum occurs only at high altitude. ML tree based on mtDNA COI gene revealed a clear separation of $C$. montanum from C. vernale.

Description. Male (holotype). $\mathrm{L}=15 \mathrm{~mm}$.

Head. Eye pile straight and yellow, denser and longer on the dorsal surface; vertical triangle black, with long black pile and white pollinosity on the posterior corners; frontal triangle black, shiny except for the white pollinosity posteriorly, black haired; antenna black; scape and pedicel with black pile; arista bare, dark brown; $r=1: 0.8: 1.8$; face yellow, yellow haired on the lower part and black haired on the upper part; face with a central black vitta extending from antennal bases to mouth edge (vitta as wide as a fourth of the face 

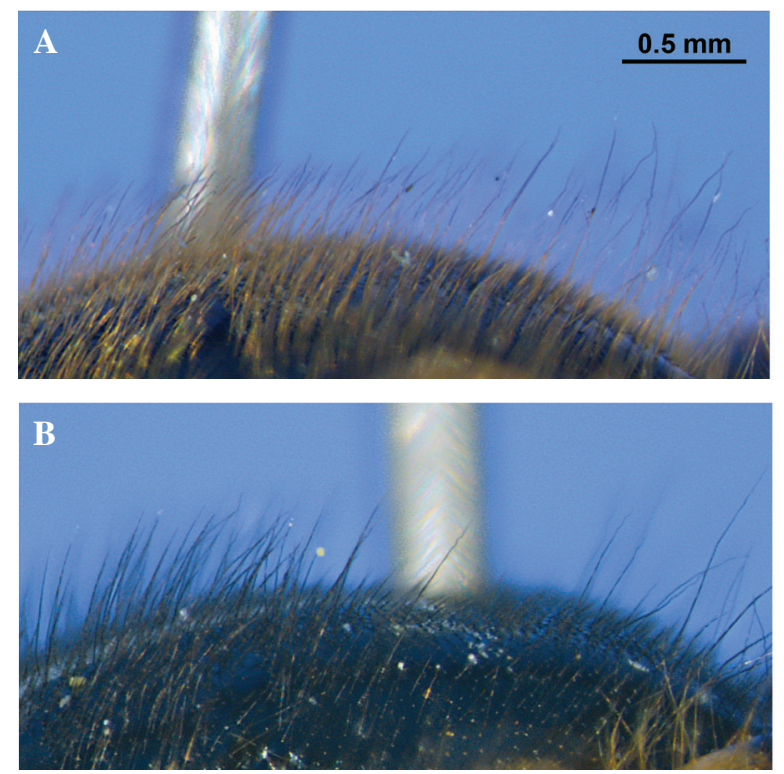

Fig. 8. Thoracic scutum of males, lateral view. A, Chrysotoxum vernale; $\mathrm{B}$, Chrysotoxum montanum sp. nov.

width); mouth edge narrowly black; gena shiny yellow and yellow-haired; occiput white pollinose, with long black pile.

Thorax. Scutum black with two central, silverypollinose vittae extending for two thirds of the scutum length from its anterior margin; scutum with both long and short black pile intermixed (Fig. 8B); katepisternum completely black (Fig. 9C); scutellum yellow except for a black central disc and lateral corners, with long black pile; legs yellow except for the black basal third of femora; wing membrane extensively microtrichose; wing cells $\mathrm{R}_{1}$ and $\mathrm{R}_{2+3}$ brown pigmented.

Abdomen. Shiny black, with short black pile, except for the yellow-haired tergum 1 and anterior part of tergum 2; all terga with two yellow fasciae not reaching the lateral margins (Fig. 11A); all terga with black pile except for the yellow pile on the fasciae; all sterna shiny black and with yellow pile; anterior margin of sternum 3 with two interconnected yellow fasciae reaching the lateral margins; anterior margin of sternum 4 with two yellow maculae reaching the lateral margins.

Genitalia. Surstylus $2.5 \times$ longer than wide (Fig. $13 \mathrm{~A}$ ); triangular-shaped hypandrium, $1.5 \times$ longer than its basal width; surstylus 1.27-1.33 times longer than hypandrium (excluding superior lobes and aedeagus).

Female. Similar to the male except for the following characters: frons with two triangular maculae of silvery pollinosity; frons and scutum with short black pile.

Geographic distribution. Austria, Bosnia \& Herzegovina, FYR Macedonia, Montenegro, Serbia (Fig. 14A).

Etymology. The epithet montanum means 'belonging to a mountain' and refers to the fact that this species is associated with mountain habitats.

Flight period. Early May to late August.

Habitat and flowers visited. This species has been found with other Chrysotoxum species in the grassy edges of conifer forests at high altitudes. Flowers visited: no data.

Table 2. Diagnostic comparison between C. montanum sp. nov. and C. vernale based on traditional morphology.

\begin{tabular}{lll}
\hline Character & C. vernale & C. montanum sp. nov. \\
\hline $\begin{array}{l}\text { Male and female } \\
\text { Colour of face pile }\end{array}$ & yellow & black on the upper part of face \\
$\begin{array}{l}\text { Colour of occiput pile } \\
\text { Colour of scutellum pile }\end{array}$ & yellow & black \\
$\begin{array}{l}\text { Colour of scutum pile } \\
\text { Katepisternum }\end{array}$ & yellow & black \\
\hline Male & with a yellow macula (Fig. 9B) & black (Fig. 8B) \\
Colour of vertical triangle pile & & black (Fig. 9C) or with a small yellow macula \\
Colour of frontal triangle pile & yellow except for some & black \\
Ratio length/width of surstylus (lateral view) & black pile posteriorly & \\
\hline
\end{tabular}

Female

Shape of frontal pollinose maculae rectangular triangular 
Taxonomic notes. In this new species, the katepisternum colour ranges from completely black (Fig. 9C) to black with a small yellow macula anteriorly. Chrysotoxum montanum sp. nov. can be separated
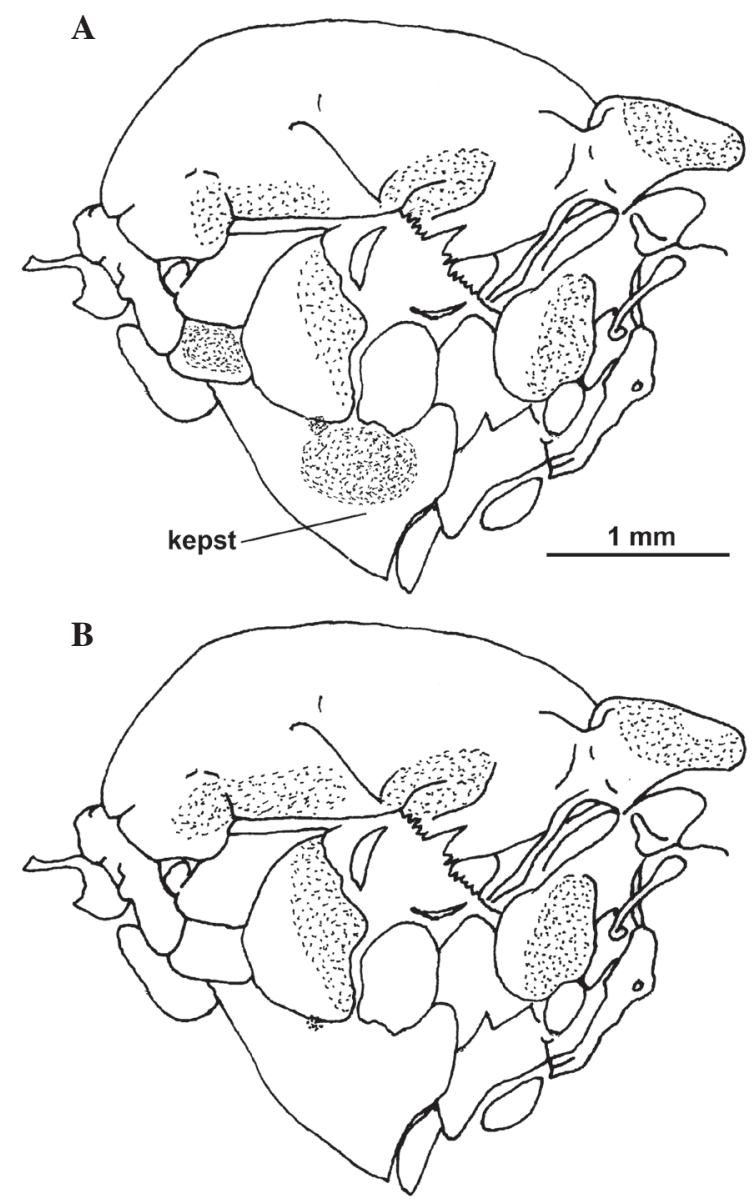

C

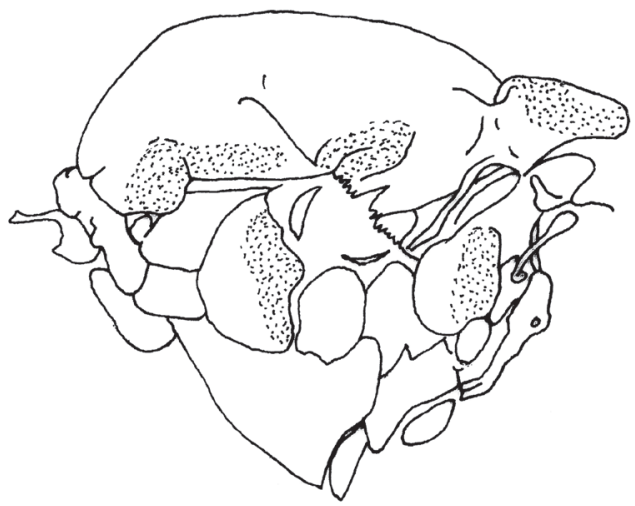

Fig. 9. Thoracic pleura, lateral view. A, Chrysotoxum orthostylum sp. nov.; B, Chrysotoxum vernale; C, Chrysotoxum montanum sp. nov. Dotted areas indicate yellow colour (kepst, katepisternum). from $C$. orthostylum sp. nov. and $C$. vernale by the colour of the long pile on the scutum, which are black in C. montanum sp. nov. (Fig. 8B) and yellow in the other species. For further morphological differences between $C$. montanum sp. nov. and $C$. vernale see Table 2 .

Chrysotoxum orthostylum Vujić sp. nov.

(Figs 9a, 10a, 10b, 11b, 12a, b; 13b)

Holotype. male, FYR MACEDONIA, Golema poljana, 14.VI.1975, leg. S. Glumac, (S11248), (FSUNS).

Paratypes. KYRGYZSTAN: 1m, Tash-Arik, Talas, 4.VI.1992, leg. Jirousek, (S11448) (DD); FYR MACE-

A

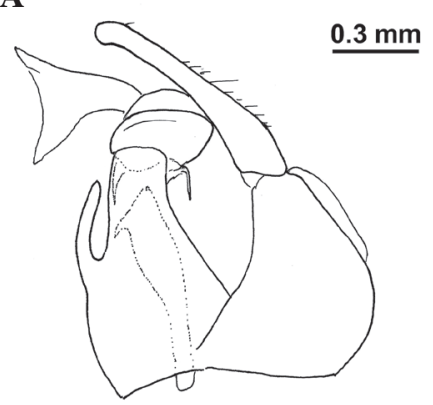

B

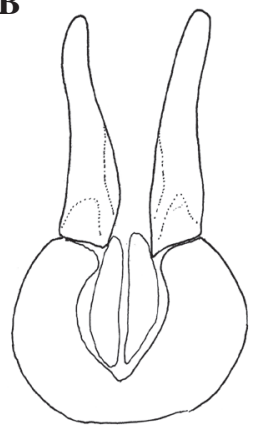

C
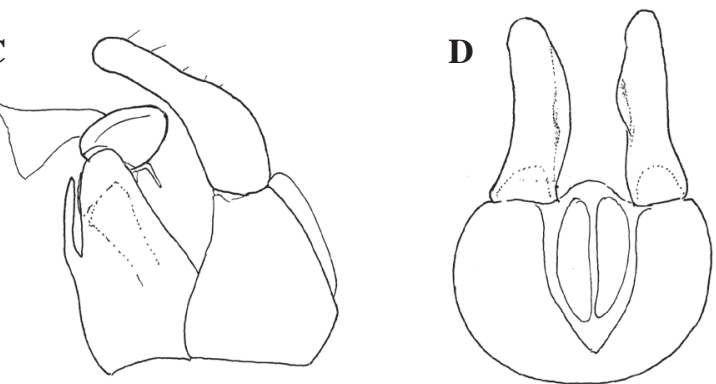

E

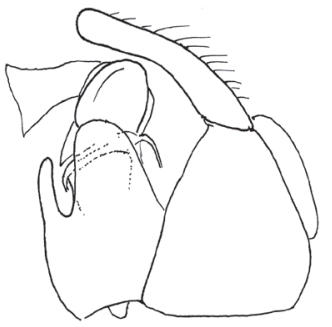

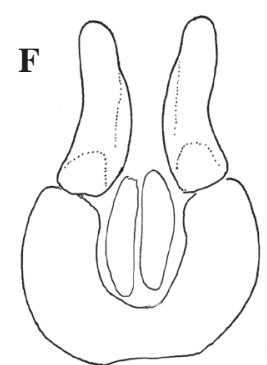

Fig. 10. Male genitalia. A, Chrysotoxum orthostylum sp. nov., lateral view; B, Chrysotoxum orthostylum sp. nov., dorsal view; C, Chrysotoxum festivum, lateral view; D, Chrysotoxum festivum, dorsal view; E, Chrysotoxum vernale, lateral view; F, Chrysotoxum vernale, dorsal view. 
DONIA: 3m, Kočani, vlažna livada, na lišću Lapsana - Chrysanthemum, 3.VI.1960, leg. Glumac (S11246, S11251, S11448); 1m, NP Pelister, 24.VII.1956. (S11247); 1f, Carevec, Bistra planina, 1.VII.1972, leg. Ćingoc (S11249); 1m, Kožuf, Golema poljana, 14. VI.1975 (S11248); 1m, Goten planina, 27.V.1988, leg. Krpač (S11252); 1m, 2f, Mavrovo, Carevec, 17.VI.1994, leg. Mihajlova (S11250, S11253, S11254); MONTENEGRO: 1m, Durmitor, Kanjon Sušice, 6.VII.1994, leg. Radenković (S11447); SERBIA: 1m, Kopaonik, Samokovska reka, 22.VI.1991, (S06316); TURKEY: $1 \mathrm{~m}$, Gurun, Mezikiran Gecidi, 10.VII.1997, leg. Mazıkıran Geçidi (S11245).

Diagnosis. Large to medium size species (14-17 mm, $\mathrm{n}$ $=9) ; r=1: 0.9: 1 ;$ scutum with short black pile which are either intermixed with long yellow pile (male) or not (female); katepisternum with a yellow macula extending on most of its dorsal margin (Fig. 9A); posterior corners of terga 3 and 4 developed in thorn-like processes (Fig. 12A); male surstylus elongate, $3.7 \times$ longer than wide (Fig. 13B); surstylus as long as hypandrium (excluding superior lobes and aedeagus) (Fig. 10A); epandrium plus surstylus 1.5-1.6 times longer than hypandrium (excluding superior lobes and aedeagus) (Fig. 10A); in female frons black, with two rectangular pollinose maculae.

Highly significant differences in wing shape were shown between $C$. orthostylum sp. nov. and $C$. vernale and $C$. montanum sp. nov. mtDNA COI haplotype of
C. orthostylum sp. nov. is genetically the most divergent to $C$. vernale and C. montanum sp. nov.

Description. Male (holotype). $\mathrm{L}=14.5 \mathrm{~mm}$.

Head. Eye pile straight and yellow, denser and longer on the dorsal half of the eye surface; vertical triangle black, with black pollinosity on the anterior corner and silvery-white pollinosity posteriorly, black-haired except for some yellow pile anteriorly; eye contiguity about 17-facets long; frontal triangle black, with long, black and yellow pile intermixed; antenna black, with black pile on scape and pedicel; arista dark brown and bare; $r=1: 0.9: 1$; face tuberculated, yellow and yellowhaired; face with a central black vitta extending from antennal bases to mouth edge (vitta as wide as a fourth of the face width); genae yellow with yellow pile; occiput white pollinose, with long yellow pile.

Thorax. Scutum black with two central, silverypollinose vittae extending for two thirds of the scutum length from its anterior margin; scutum with long yellow pile, intermixed with short black pile on the posterior part; katepisternum with a yellow spot on the dorsal margin (Fig. 9A); scutellum yellow with a black central disc, covered with long yellow and short black pile; legs yellow except the black basal third of proand mesofemora; leg pile yellow; wing wholly microtrichose; halter completely yellow; cells $\mathrm{R}_{1}$ and $\mathrm{R}_{2+3}$ brown pigmented.

Abdomen. Elongate, parallel-sided (Fig. 11B); shiny black with short black pile, except for the yellow-
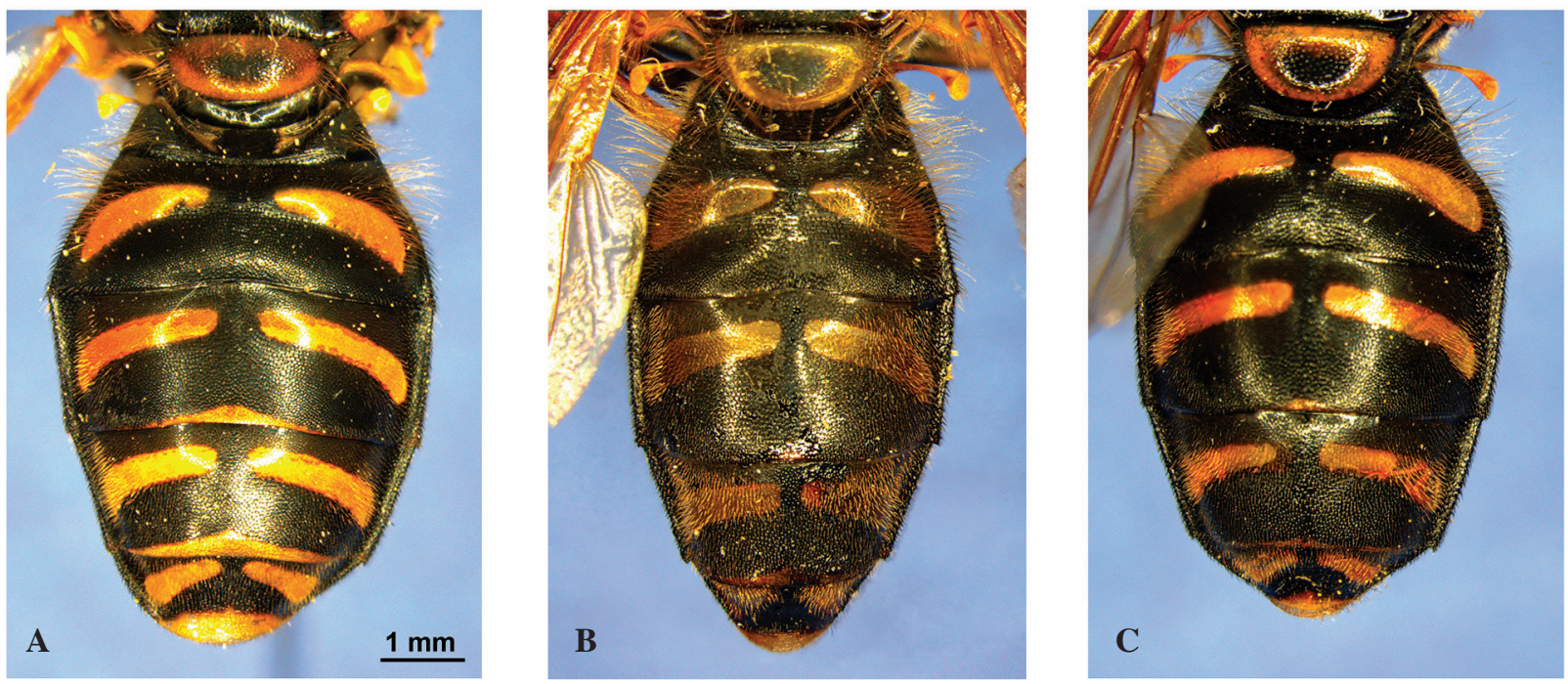

Fig. 11. Abdomen, dorsal view. A, Chrysotoxum montanum sp. nov.; B, Chrysotoxum orthostylum sp. nov.; C, Chrysotoxum vernale. 

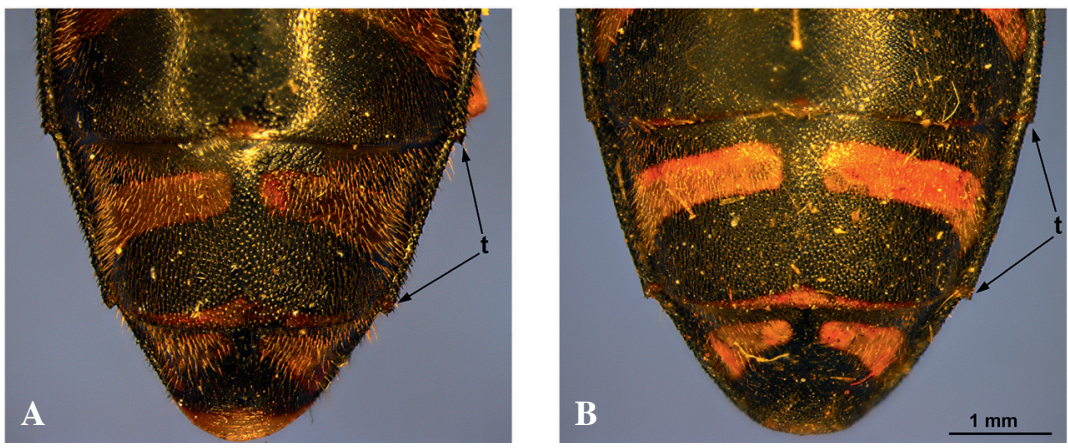

Fig. 12. Terga 3-5, dorsal view, Chrysotoxum orthostylum sp. nov. A, male; B, female ( $\mathrm{t}$, thorn-like process).

haired tergum 1 and anterior part of tergum 2; all terga with two yellow and yellow-haired fasciae (Fig. 11B); posterior corners of terga 3 and 4 developing in thornlike processes (Fig. 12A); all sterna shiny black and yellow haired; anterior margin of sternum 3 with two interconnected yellow fasciae not reaching the lateral margins; anterior margin of sternum 4 with two yellow maculae not reaching the lateral margins.

Genitalia. (Fig. 10A, B): Elongate surstylus, 3.7x longer than wide (Fig. 13B); triangular-shaped hypandrium, 1.2 times longer than its basal width (Fig. 10A).

Female. Similar to the male except for the following characters: frons black with two rectangular pollinose maculae; frons with short black pile; scutum only with short black pile.

Geographic distribution. FYR Macedonia, Kyrgyzstan, Montenegro, Serbia, Turkey (Fig. 14B).

Etymology. The noun in apposition orthostylum means 'straight stylus' and refers to the fact that the male surstylus is straight and more elongated than that in similar species.

Flight period. Mid May to mid August.

Habitat and flowers visited. Chrysotoxum orthostylum sp. nov. has been found flying with other Chrysotoxum species in the grassy edges of conifer forests at high altitudes in Serbia and Montenegro. In FYR Macedonia, $C$. orthostylum sp. nov. has been found resting on Lapsana and Chrysanthemum leaves in wet meadows.

Taxonomic notes. Chrysotoxum orthostylum sp. nov. can be distinguished from C. montanum sp. nov. and $C$. vernale by the abdomen shape, which is slender and nearly parallel-sided in $C$. orthostylum sp. nov. (Fig. 11B) but more oval in other species (Fig. 11A, C). In addition, the posterior corners of tergites 3 and 4 in C. orthostylum sp. nov. are developed into thorn-like processes (Fig. 12A, B), while in similar species these corners are blunter. The katepisternum of $C$. orthostylum sp. nov. has a yellow macula (Fig. 9A), which is more reduced or even absent in C. vernale and C. montanum sp. nov. (Fig. 9B, C). Males of C. orthostylum sp. nov. can be separated from other species by the long surstylus, which is $3.3-3.7 \times(\mathrm{n}=5)$ longer than wide in $C$. orthostylum sp. nov. (Fig. 13B) but $2.8 \times$ or less in the other species (Fig. 13A, C). In addition, the shape of the hypandrium apex is rectangular in C. orthostylum sp. nov. (Fig. 10A) and more triangular in $C$. festivum (Fig. 10C) and C.vernale (Fig. 10E).

Variability. In C. orthostylum sp. nov. the colour of legs ranges from dark yellow to black in basal third of pro- and mesofemora and in basal two thirds of metafemora. In addition, southern specimens (FYR Macedonia) have wider and lighter yellow fasciae on terga than specimens from more localities further north.

Chrysotoxum vernale Loew, 1841

(= morphotype A sensu Nedeljković, 2011)

(Figs 8a, 9b, 10e, 10f, 11c, 13c)

syn. collinum Rondani, 1857: 202

syn. flavipenne Palma, 1864: 40

syn. fuscum Giglio-Tos, 1890: 160

syn. vernaloides Giglio-Tos, 1890: 161

Chrysotoxum vernale was described from an unspecified but large ("Unter vielen Exemplaren...") number of specimens, both males and females. Some males studied by Hermann Loew were collected in the place where he was working at the time of the description (“...hier gefangen...”): Poznań ("Posen”), Poland. Apart from this, no other data about the type locality of $C$. vernale are given in the original description. In the ZMHB there are 27 specimens of $C$. vernale belonging to Loew's collection (J. Ziegler, in lit.); of these 
specimens only 20 are labelled as 'Coll. H. Loew' and further information is not provided in the available data bases at the ZMHB (Sven Marotzke, in lit.). These specimens were examined here to confirm the colour of scutum pile, which was yellow. Two named specimens (male and female) of $C$. vernale from the 'old collection' ("Alte Sammlung") at the NHMW were also examined; the female is labelled as 'Chrysotoxum vernale f Loew*' (handwritten). No information about the locality where the NHMW specimens were collected is available, but Loew's type material is usually marked with an asterisk (*) (A. Vujić, pers. obs.). We
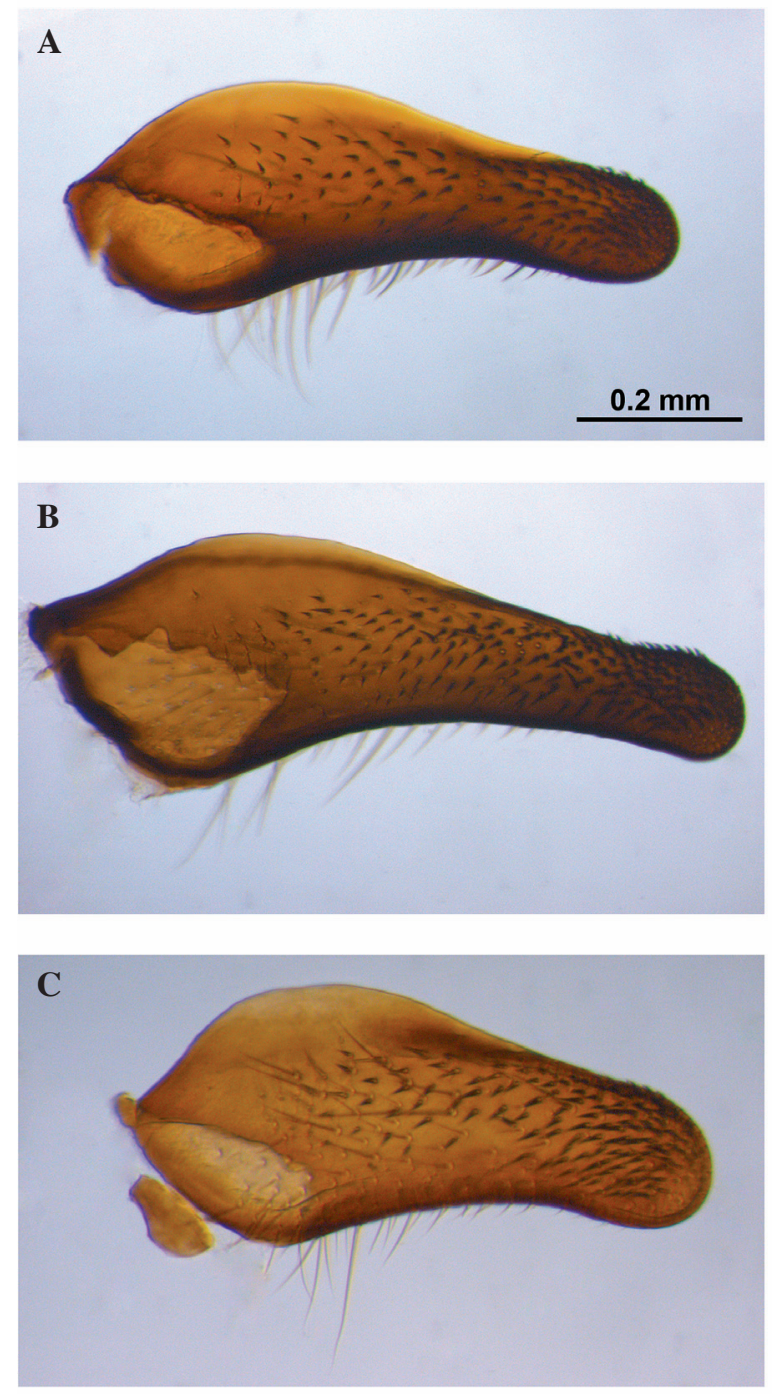

Fig. 13. Right surstylus of the male genitalia, lateral view. A, Chrysotoxum montanum sp. nov.; B, Chrysotoxum orthostylum sp. nov.; C, Chrysotoxum vernale. consider that the specimens examined both in ZMHB and NHMW belong to the type series of $C$. vernale and the NHMW male is designated as lectotype in order to stabilize this species concept.

Chrysotoxum flavipenne was described from a single male. The description provided by Palma (1863) is detailed enough and indicates that the scutum pile are yellow ("Torace...rivestito nel dorso da gialla peluria...") and the thoracic pleuron has a yellow macula ("...ampia macchia triangolare dello stesso colore su ciascun fianco"). The repository collection of the $C$. flavipenne holotype is unknown to the authors of the present paper; it might be deposited in the entomological collection at the Museo Zoologico, Centro Musei delle Scienze Naturali, Naples, Italy but this collection is now being inventoried (Roberta Improta, in lit.). Giglio-Tos (1890) diagnosed Chrysotoxum fuscum and compared it with $C$. vernale of Loew. Giglio-Tos (1890) also noted the existence of Chrysotoxum vernaloides as a variety of C.fuscum. According to the original description of C.fuscum the colour of the scutum pile is yellow ("Thorace fulvo piloso"); the variety vernaloides differed from other C. fuscum specimens in characters other than the thoracic pile (Giglio-Tos, 1890). Sommaggio (2001) proposed C. fuscum and $C$. vernaloides as junior synonyms of $C$. vernale upon examination of the type material and designated lectotypes for these two names. These two lectotypes are deposited at the entomological collection of the Museo Regionale di Scienze Naturali, Torino, Italy. However, this museum suffered a fire in 2013 and the collections are still inaccessible to users; Giglio-Tos' collection is undamaged (Marinella Garzena, in lit.). Based on the original descriptions of $C$. flavipenne, $C$. fuscum and $C$. vernaloides, as well as on the nomenclatural and taxonomic advances made by Sommaggio (2001), we confirm these three names as synonyms of $C$. vernale. In addition, the holotype of $C$. collinum was examined by the authors of the present study on the basis of four images made by Dr Luca Bartolozzi (LSF): dorsal, lateral and ventral overall views and anterior view of the face. This specimen was also confirmed to be the typical C. vernale.

\section{Material examined.}

Lectotype (designated here): $1 \mathrm{~m}$ labelled as 'vernale, Schlerin'/ 'Alte Sammlung' / S11470 (NHMW).

Paralectotypes (designated here). if labelled as 16/547/ vernale f Loew Alte Sammlung/ Austria Alte Sammlung/ Chrysotoxum vernale f Loew* (NHMW). 20 specimens labelled as 'Coll H. Loew' and seven 

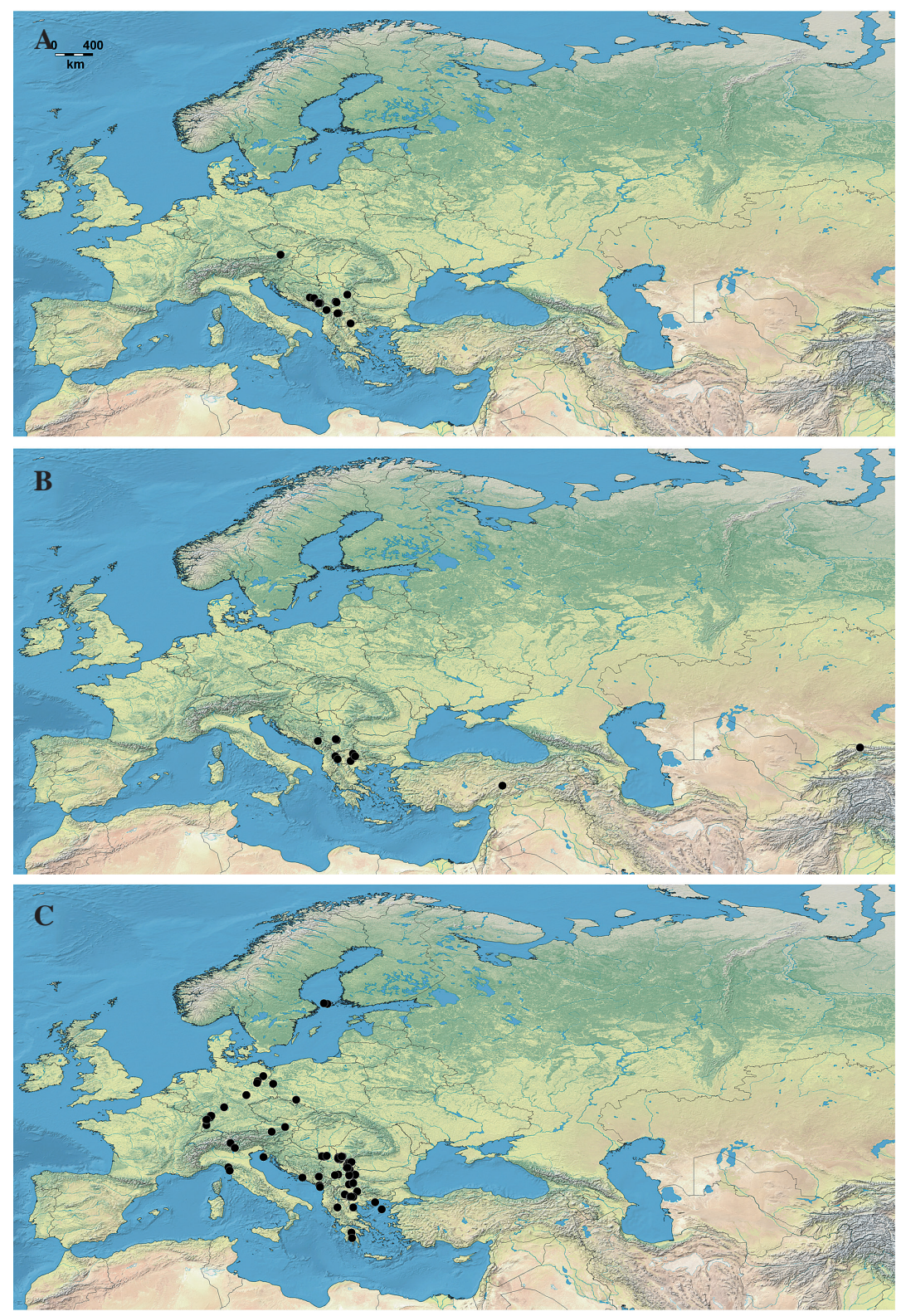

Fig. 14. Distribution maps of the material examined. A, Chrysotoxum montanum sp. nov.; B, Chrysotoxum orthostylum sp. nov.; C, Chrysotoxum vernale. specimens not labelled but supposed to be part of Loew's collection and have been collected in Poznań (J. Ziegler, in lit.); 10 of the 20 'Coll H. Loew' specimens are labelled as 'Wien Schiner' (4 specimens), 'Florenz Mann' (3 specimens), 'Syrakus Zeller' (1 specimen), 'Spanien’ (1 specimen), 'Paris' (1 specimen) (ZHMB).

Additional material. Holotype of Chrysotoxum collinum: m, Museo "La Specola" coll. Rondani HOLOTYPUS (red label)/ 357/ Chrysotoxum vernale (= col- linum Rnd.)/ rev. (overwritten by hand on 'det.') M. Daccordi 1985 [LSF]. For further non-type additional material see Table S1.

Diagnosis. Large to medium size species (11-15 mm, $\mathrm{n}$ $=10) ; \mathrm{r}=1: 0.6: 1.5$; vertical and frontal triangle with yellow pile; scutum with long yellow pile (male) (Fig. 8A); katepisternum with a yellow macula (Fig. 9B); scutellum mainly with long yellow pile; basal third of pro- and mesofemora black; surstylus 1.2-1.3 times 
longer than hypandrium (excluding superior lobes and aedeagus) (Fig. 13C); epandrium plus surstylus 1.1-1.2 times longer than hypandrium (excluding superior lobes and aedeagus) (Fig. 10E); in female, frons black, with two rectangular pollinose maculae. Chrysotoxum vernale has larger wings than C. montanum. Additionally, it has wide temperature, precipitation and altitude range.

Geographic distribution. (only localities confirmed in the present study): Austria, Croatia, Finland, Germany, Greece, Italy, FYR Macedonia, Montenegro, Poland, Serbia (Fig. 14C).

Flight period. Mid April to mid-August.
Habitats and flowers visited. In Europe, C. vernale is found in the following habitats: forests; open woodlands and scrubs on well-drained sites, from Betula invaded heathland to Fagus woodlands to Genista florida/Quercus pyrenaica maquis; also in welldrained, unimproved grasslands, including montane and alpine grasslands (up to $2500 \mathrm{~m}$ ). It is known to visit white flowers of Umbelliferae, as well as those of Caltha, Crataegus, Euphorbia, Helianthemum, Sorbus, Valeriana (Speight, 2013).

Taxonomic notes. To separate this species from the similar C. montanum sp. nov. see Table 2.

\section{Adjustments to the Palaearctic Chrysotoxum key}

Refinements to couplets in the key to the Palaearctic Chrysotoxum in Violovitsh (1974) are provided below, based on the results presented here, as well as those in Nedeljković et al. (2013). Chrysotoxum montanum sp. nov., C. vernale and specimens of $C$. orthostylum sp. nov. with femora black basally would key out to C. vernale (sensu lato) in Violovitsh (1974); specimens of C. orthostylum sp. nov. with femora wholly yellow would key out to Chrysotoxum festivum (Linnaeus, 1758) (s. l.). Chrysotoxum festivum and Chrysotoxum tomentosum Giglio-Tos, 1890, which also have yellow fasciae on terga 2-4 not reaching the lateral margins of tergum, would key out to C. festivum (s. l.).

Chrysotoxum festivum, C. orthostylum sp. nov. (femora wholly yellow), and C. tomentosum

Males - change step 46

46 (47). Femora of all legs yellow.

a (b). Posterior corners of terga 3 and 4 developed into thorn-like processes (Fig. 12A); male surstylus elongate, $3.7 \times$ longer than wide (Fig. 13B)

C. orthostylum sp. nov.

b (a). Posterior corners of terga 3 and 4 without or with very inconspicuous thorn-like processes; male surstylus 1.5-2.8× longer than wide.

c (d). Scutum with long yellow pile only (figure 5A: Nedeljković et al., 2013); mouth edge yellow

d (c). Scutum with long yellow pile and short black pile intermixed (figure 5B: Nedeljković et al., 2013); mouth edge black

C. tomentosum

Chrysotoxum montanum sp. nov., C. orthostylum sp. nov. (femora black basally), and C. vernale

Males - change step 47

47 (46). Pro- and mesofemora dark brown to black at least basally.

a (b). Abdomen slender, 1.8 $\times$ longer than wide; posterior corners of terga 3 and 4 developed into thorn-like processes (Fig. 12A); male surstylus elongate, 3.7× longer than wide (Fig. 13B)

C. orthostylum sp. nov.

b (a). Abdomen more oval, 1.4-1.6× longer than wide (Figs. 11A, C); posterior corners of terga 3 and 4 without or with very inconspicuous thorn-like processes; male surstylus $2.5-3 \times$ longer than wide (Figs. 13A, C).

c (d). Scutum with yellow pile only (Fig. 8A); katepisternum with a yellow macula (Fig. 9B)

C. vernale

d (c). Scutum with black pile only (Fig. 8B); katepisternum completely black (Fig. 9C)

C. montanum sp. nov. 
Chrysotoxum festivum, C. orthostylum sp. nov. (femora wholly yellow), and C. tomentosum

Females - change step 36

36 (37). Femora of all legs yellow.

a (b). Abdomen slender, $2 \times$ longer than wide; posterior corners of terga 3 and 4 developed into thorn-like processes (Fig. 12B)

C. orthostylum sp. nov.

b (a). Abdomen more oval, 1.6-1.7x longer than wide; posterior corners of terga 3 and 4 not developed into thorn-like processes, or very inconspicuously developed.

c (d). Pollinose maculae on frons triangular

C. tomentosum

d (c). Pollinose maculae on frons rectangular

C. festivum

Chrysotoxum montanum sp. nov., C. orthostylum sp. nov. (femora black basally), and C. vernale

Females - change step 37

37(36). Pro- and mesofemora dark brown to black at least basally.

a (b). Abdomen slender, $2 \times$ longer than wide; posterior corners of terga 3 and 4 developed into thorn-like processes (Fig. 12B)

C. orthostylum sp. nov.

b (a). Abdomen more oval, 1.6-1.7× longer than wide; posterior corners of terga 3 and 4 not developed into thorn-like processes, or very inconspicuously developed.

c (d). Pollinose maculae on frons triangular

C. montanum sp. nov.

$\mathrm{d}$ (c). Pollinose maculae on frons rectangular

C. vernale 